POST-PRINT AUTHOR COPY

ACCEPTED IN JOURNAL OF PERSONAL SELLING AND SALES MANAGEMENT

DECEMBER 18, 2017

DOI: https://doi.org/10.1080/08853134.2017.1415761

(RE) DEFINING SALESPERSON MOTIVATION:

CURRENT STATUS, MAIN CHALLENGES AND RESEARCH DIRECTIONS

Rushana Khusainova

Aston Business School

Aston University

Birmingham, United Kingdom, B4 7ET

Ad de Jong

Professor of Marketing

Marketing and Strategy Group

Aston Business School

Aston University

Birmingham, United Kingdom, B4 7ET

Nick Lee

Professor of Marketing

Marketing Group

Warwick Business School

University of Warwick

Scarman Rd.

Coventry, United Kingdom, CV4 7AL

Greg W. Marshall

Charles Harwood Professor of Marketing and Strategy

Rollins College

Crummer Graduate School of Business

1000 Holt Avenue, Campus Box 2722

Winter Park, Florida, USA 32789-4044

Honorary Professor of Marketing and Strategy

Aston Business School

Birmingham, United Kingdom, B4 7ET

John M. Rudd

Professor of Marketing

Marketing Group

Warwick Business School

University of Warwick

Scarman Rd.

Coventry, United Kingdom, CV4 7AL 


\title{
(Re) defining salesperson motivation: \\ Current status, main challenges, and research directions
}

\author{
Author Information
}

Rushana Khusainova, Doctoral Candidate, Aston Business School, Aston University, Birmingham, United Kingdom, B4 7ET, Phone: +44 (0)121 204 3219, Email: khusair1 @aston.ac.uk.

Ad de Jong, Professor of Marketing, Marketing and Strategy Group, Aston Business School, Aston University, Birmingham, United Kingdom, B4 7ET, Phone: +44(0)121 204 3227, Email: a.dejong@aston.ac.uk.

Nick Lee, Professor of Marketing, Marketing Group, Warwick Business School, University of Warwick, Scarman Rd., Coventry, United Kingdom, CV4 7AL, Phone: +44 (0)247 652 8674, Email: Nick.Lee@wbs.ac.uk.

Greg W. Marshall, Charles Harwood Professor of Marketing and Strategy, Rollins College Crummer Graduate School of Business, 1000 Holt Avenue, Campus Box 2722, Winter Park, Florida, USA, 32789-4044, Phone: 407/691-1150, Email: gmarshall@ rollins.edu. Honorary Professor of Marketing and Strategy, Aston Business School, Birmingham, United Kingdom, B47ET.

John M. Rudd, Professor of Marketing, Marketing Group, Warwick Business School, University of Warwick, Scarman Rd., Coventry, United Kingdom, CV4 7AL, Phone: +44 (0)247 652 8657, Email: John.Rudd@wbs.ac.uk. 
(Re) defining salesperson motivation:

Current status, main challenges, and research directions

\begin{abstract}
The construct of motivation is one of the central themes in selling and sales management research. Yet, to-date no review article exists that surveys the construct (both from an extrinsic and intrinsic motivation context), critically evaluates its current status, examines various key challenges apparent from the extant research, and proposes new research opportunities based on a thorough review of past work. We explore how motivation is defined, major theories underpinning motivation, how motivation has historically been measured, and key methodologies employed over time. In addition, attention is given to principal drivers and outcome of salesperson motivation. A summarizing appendix of key articles in salesperson motivation is provided.
\end{abstract}

Keywords: Salesperson, motivation, review, sales management 


\section{(Re) defining salesperson motivation: Current status, main challenges, and research directions}

Salesperson motivation has long been considered to be one of the critical tasks of sales management (Doyle and Shapiro 1980; Jaramillo et al. 2005). If the interested manager was to peruse the academic literature, he or she would find a rich body of work on the topic but might find just as much ambiguity in terms of advice on how best to motivate salespeople. Indeed, sales scholars have expended significant effort on investigating salesperson motivation, creating a large and growing body of knowledge regarding how salespeople can be motivated, investigating the various forms of salesperson motivation, and exploring the effects of different forms of motivation on different forms of salesperson performance. Research has also exposed the different managerial interventions can be brought to bear on increasing the different forms of salesperson motivation including monetary and nonmonetary rewards, job designs, and interpersonal managerial styles and techniques. Taken together, the existing body of research on salesperson motivation places motivation as one of the most enduringly popular topics of sales research (Pullins 2001; Walker et al. 1977; Williams and Plouffe 2007). However, there is a number of inconsistencies and ambiguity within the research domain, and a number of conflicting research findings. In addition, it does not provide a clear and unambiguous set of advice for managers as to what works, when, and why. Hence, a review article across the salesperson motivation literature should be timely and quite useful.

\section{Roots and premises of salesperson motivation research}

Research into salesperson motivation dates back to the 1970s, when sales and marketing researchers first began to explore this important area as key driver of sales performance (Churchill et al. 1976). Of course, pre-dating this were hundreds of studies within the psychological literature that explored how extrinsic rewards could shape behaviors, thus serving to build a strong base for general motivational research. In the early 1970s, the idea that some activities could serve as their own intrinsic reward emerged (e.g. Deci 1971), thus setting up what appears to be a continuing dichotomy between extrinsic and intrinsic motivations. Indeed, the divergence in sales practitioner-oriented work noted above can to some extent be traced back to this dichotomy, which remains salient in academic research. A number of reviews of motivation literature have appeared in the management literature that take in these differences. The most recent of these stresses that "motivation related to work remains one of the most enduring and compelling topics in industrial/organizational (I/O) psychology” (Kanfer et al. 2017, 338). However, while I/O psychology does not lack for 
reviews of motivational research, sales-specific research lacks a wide-ranging overview regarding the specific nature of the various different forms of motivation, and how these affect salesperson performance and other important job outcomes.

The lack of a prior comprehensive review of sales force motivation literature is a bit troubling as it leaves a number of important questions unanswered regarding the state of the literature and its potential contribution to the knowledge of salesperson performance. More specifically, as alluded to above, there remains little consensus on exactly how best to motivate salespeople, and a continuing challenge remains for example regarding whether it is best to use financial incentives, nonfinancial rewards, or rely on job design factors to generate intrinsic motivation. The purpose of the present review is to integrate our existing knowledge in sales force motivation, and thus more clearly delineate the current state of the art in sales force motivation research, identify gaps and inconsistencies in current academic knowledge of sales force motivation, and present an informed agenda for future research in the area that will both advance the body of knowledge and provide more coherent advice to practitioners. In doing so, we aim to deliver for sales force motivation research the currently missing "research integration and synthesis [that] provides an important, and possibly even a required, step in the scientific process" (Palmatier et al. 2017).

The need to clarify knowledge on sales force motivation suggested above is amplified by a variety of well-document recent changes in the sales domain. Businesses have been going through numerous changes in the way sales organizations operate (Keszey and Biemans 2016). The beginning of this so-called revolution in sales (Marshall et al. 2012) could be dated back to the beginning of the century when the sales role was described as being in the heart of a "renaissance - a genuine rebirth and revival" (Ingram et al. 2002, 552). Since then, there has been a dramatic evolution in the salesperson's role in the organization towards that of a business/development/consultant (Keszey and Biemans 2016; Narus 2015), who is heavily technology savvy (Marshall et al. 2012), and a vital knowledge broker (Verbeke et al. 2011). An array of other advances, such as new sales technologies that support and improve the sales processes (Kuruzovich 2013) and the emergence of big data (Erevelles et al. 2016), have changed the landscape in which salespeople operate. Further to this, the implementation of team-based structures (Stock 2006) and global virtual sales teams (Badrinarayanan et al. 2011) and groupware technology (Janson et al. 2014) have also transformed the way sales organizations function. Also, recent years have seen significant changes in the composition of many sales forces, with inside sales roles making up an 
increasingly higher proportion of sales roles when compared with traditional field sales roles (Zoltners et al. 2013)

The dramatic shifts in the role of the salesperson touched on above are accompanied by a significant demographic change in the sales workforce. Specifically, as the prior generations reach retirement age and moves out of the workforce, new salespeople are increasingly being recruited from the ranks of what millennial generation, which is predicted to reach almost 50 percent of the workforce by 2020 . Evidence suggests that they are motivated significantly differently from early generations such as Baby Boomers and Generation X (Brack and Kelly 2012). Both academic research and practitioner publications have also suggested that millennials in sales roles are motivated and perform in a manner different from earlier generational cohorts (Pullins et al. 2011; Schultz et al. 2012)

The aforementioned changes in the sales job, and the people doing it, likely necessitate some fundamental changes in sales force motivation strategies, which calls for a better and more detailed understanding of individual salesperson motivation. However, without a strong appreciation of the state of the literature to date, it is difficult to provide any informed and coherent agenda for future research in salesperson motivation. As such, it is timely to review what we have learned about salesperson motivation and from there begin to envision what else is to come in the field. As such, the primary purpose of this paper is to provide a comprehensive literature review of the topic of salesperson motivation, from its beginnings as a unique field of study in the 1970s, up to 2017. Within this broad charge, we have three key goals. First, we aim to delineate the key theoretical and methodological pillars of existing work on salesperson motivation. Second, we draw from our review to identify key challenges and future research directions for the field of salesperson motivation. And third, we proffer critical recommendations for the future focus of sales management practice from this literature. Importantly, we do not attempt to review the huge body of motivation research that is not specifically sales-related (although we certainly acknowledge that the salesperson motivation literature has been substantially impacted by it). Our focus in this review is on salesperson motivation only.

The paper is structured in the following way. We initially describe the review methodology. We then outline how motivation is defined in the literature. We present the main theories, measurements and methodologies utilized in the area of salesperson motivation. We then present a summary of the main findings in the literature on the drivers and outcomes of salesperson motivation. Finally, we conclude with key proposals for future research directions. 


\section{Review methodology}

In undertaking the review presented in this paper, key principles of a systematic review were adopted (Barczak 2017; Palmatier et al. 2017). A systematic literature review has been recognized as a highly effective and transparent method for gathering and analyzing a body of knowledge in a specific research field (Shojania et al. 2007). Applying the key principles of the systematic review methodology can substantially enhance the quality of a review by making the ideas and assumptions behind a review more explicit (Tranfield et al. 2003) and by minimizing error and bias (Cook et al. 1997). Indeed, Palmatier et al. (2017) recommend that a systematic approach is best used for literature reviews, rather than a narrative approach, which can lead to an overly descriptive approach that lacks critical assessment of the body of literature for additional guidance (see also Barczak 2017).

Focus of the present literature review is salesperson motivation, hence we primarily concentrate on sales, marketing, and management/business literature in line with previous conceptual work in sales domain (e.g. Moncrief et al. 2000). Obviously, much work has been conducted on the topic of general employee motivation in the wider I/O psychology domain, as summarized by Kanfer et al. (2017). Our position is that we are "informed by" the theoretical and empirical findings from in a wider psychology literature to enrich our understanding of salesperson motivation and to support the proposed future research directions. But the focus here on motivation in the sales domain is clearly defendable, as sales is well documented as a unique job set and environment, as mentioned earlier.

The current review is conducted in a funneling manner where each step feeds into the next leading to an increasingly more precise focus (Stros and Lee 2015). More specifically, an initial general literature review was performed to generate an overall pool of articles on the topic of salesperson motivation. Here we did not limit the search to any specific subject area or journal. The search was performed using the key search terms "motivation" and "sales" in the abstract field of the search databases (ProQuest Business Collection, ABI/INFORM Collection, ABI/INFORM Global and Entrepreneurship Database). This resulted in 2,957 hits. After eliminating trade journals, wire feeds, conference proceedings, magazines and newspapers, the pool of articles came down to 560 hits. Following this, we only included peer reviewed journals which resulted in a pool of 507 articles. The next step was to filter by document type. Specifically, we only used journal articles (excluding such documents as features, reports, or case studies) resulting in a pool of 483 articles. We then only retained articles that were written in English, which resulted in 478 hits. The next step was to utilize a key journal criteria. We began with including 19 key journals that publish 
sales related research as described by Moncrief et al. (2000) (for similar guidance, see also Baumgartner and Pieters (2003), and Richards et al. (2010)). This resulted in 135 hits. In order to ensure that no relevant article has remained in the excluded pool, we performed a manual check of the relegated articles. Here, one additional relevant article from the Journal of Applied Psychology was identified and added into the main pool resulting in 136 entries.

The next step was to manually check all articles and eliminate those that merely had a mention of the relevant key terms in the body of the full-text, but did not specifically conceptualize or empirically/conceptually examine or investigate motivation per se. ${ }^{1}$ As previously explained, we concentrated on salesperson motivation excluding such topics as customer/consumer/shopper motivation. Secondly, it was important to further explicate the scope of the review. That is, motivation is a broad topic, and as Ryan and Deci (2000a, 54) put it, to be motivated simply means "to be moved to do something" (note that we will provide a more formal definition of motivation shortly). Therefore, motivation is often used as an "umbrella term" referring loosely to a variety of behavior-type variables (Kanfer et al. 2017). In the present review we explicitly concentrate on articles that conceptualize/examine motivation or its types (intrinsic and extrinsic). After the exclusion of such non-relevant articles, particularly those using "motivation" in the vernacular, the pool of articles came down to 57.

Again, a manual check of the citations was performed to ensure that none of the relevant articles has been missed. This resulted in additional six articles. Hence, the finalized pool of articles contains 63 papers that are from 13 different academic journals. The journals are the following: Journal of Personal Selling and Sales Management (JPSSM), Journal of Marketing (JM), Journal of Business \& Industrial Marketing (JBIM), Journal of Marketing Research (JMR), Journal of the Academy of Marketing Science (JAMS), Journal of Business Research (JBR), Industrial Marketing Management (IMM), European Journal of Marketing (EJM), International Journal of Research in Marketing (IJRM), Psychology and Marketing (P\&M), Journal of Marketing Theory and Practice (JMTP), Journal of Applied Psychology (JAP) and Journal of Business Ethics (JBE). Figure 1 below presents the key journals and the number of papers published per each journal.

\footnotetext{
${ }^{1}$ This included a number of articles that had the word "motivate" or "motivation" present in the fulltext of the document. For example, in a paper that states "the authors' motivation to examine this topic is..." or "hedonic motivation of the shoppers was..." the term "motivation" is irrelevant to the current study.
} 
Place Figure 1 about here

After the evaluation of the selected pool of articles, the information from the final pool of 63 key papers has been structured into an Appendix of this article as a means for the reader to receive details in a clear and structured manner (e.g. Hohenberg and Homburg 2016; Menguc et al. 2017; Shi et al. 2017; Stros and Lee 2015). Following their benchmarks, the Appendix represents the following information: study, year, journal, methodology, sample size and response rate, key relevant findings, theory utilized, and how motivation was measured.

\section{How motivation has been defined}

As a starting point, in a now classical paper Walker et al. $(1977,162)$ defined motivation as "the amount of effort the salesman desires to expend on each of the activities or tasks associated with his job". Moreover, motivation is a psychological state that causes the arousal, direction, and persistence of behaviors conditioned by need satisfaction (Mitchell 1982). We anchor our conceptualization on Mitchell's (1982) definition. Research on motivation disaggregate the construct into two distinct types: intrinsic motivation (IM) and extrinsic motivation (EM) (e.g. Mallin and Pullins 2009; Tyagi 1982; Weitz et al. 1986).

IM arises from enjoyment of an activity with absence of an apparent reinforcement or reward (Teo et al. 1999; Warr et al. 1979; Weiner 1995). The fundamental premise of IM is that human nature is active, curious, and inquisitive (White 1959). EM on the other hand is concerned with whether an activity is performed in order to obtain a separable outcome apart from the activity itself (Davis et al. 1992; Ryan and Deci 2000a; Teo et al. 1999).

Historically, salesperson motivation has been linked almost exclusively to pay packages and financial incentives (e.g. Oliver 1974; Walker et al. 1977). It is common to refer to this assumption as a "conventional wisdom" of salesperson motivation (e.g. Cravens et al. 1993; Wotruba et al. 1991). However, later studies have further demonstrated the crucial importance of IM in influencing salesperson effort and performance.

Following the I/O psychology literature (Amabile et al. 1994), a number of studies on salesperson motivation (Miao and Evans, 2007; Miao, Lund, and Evans, 2009) further disaggregate EM and IM into their cognitive and affective orientations which were found to have distinct antecedents and consequences (Miao and Evans 2007; Miao et al. 2007). 
Specifically, the cognitive orientation of IM is labelled "challenge seeking," while the affective orientation of IM is labelled "task enjoyment." In addition, the cognitive orientation of EM is labelled "compensation seeking," whereas the affective orientation of EM is labelled "recognition seeking." Amabile et al (1994) have specifically defined these terms as follows: Challenge seeking deals with the enjoyment of solving new and complex problems and seeking challenging tasks; task enjoyment is concerned with enjoying the selling job and finding it pleasurable; compensation seeking involves how much money one can earn in their job; and recognition seeking is concerned with receiving recognition from the others.

With a definition of motivation in hand, the following three sections outline the main theories utilized, key motivational measures used and key methodologies employed.

\section{Main theories utilized}

To-date three major theoretical underpinnings of motivation have dominated sales motivation research: expectancy theory, attribution theory, and self-determination theory (SDT). Figure 2 below illustrates their frequency of use within our pool of sales motivation articles.

Place Figure 2 about here

\section{Expectancy theory}

Historically, the prevailing theory in sales research has been expectancy theory (Vroom 1964), which was originally applied by Oliver (1974) and then by Walker et al. (1977) to create a famous model and what some might call a new paradigm for sales force management research (Johnston and Marshall 2005). Expectancy theory suggests that motivation is driven by three variables, that Vroom (1964) named expectancy, instrumentality, and valence for rewards. Expectancy (effort-performance relationship) refers to an individual's belief that applying a given amount of effort will result in performance; instrumentality (performancereward relationship) is the individual's belief that performing at a certain level will result in attainment of desired organizational rewards; and valence (rewards-personal goals relationship) - is concerned with the degree to which organizational rewards can satisfy individual's personal goals and attractiveness of these rewards to the individual (Robbins 2009). 
By the 1980s, expectancy theory was said to "dominate the sales motivation literature" (Badovick 1990, 123), and sparked much empirical work (e.g. Oliver 1974; Teas 1980, 1981; Teas and McElroy 1986; Tyagi 1982; Walker et al. 1977). The theory has been described as primarily suited in situations when effort-performance and performance-reward relationships are consciously perceived by an individual (House et al. 1974). Specifically, salespeople exert effort in order to achieve certain level of sales (performance) which directly translates into them receiving a financial reward (Kishore et al. 2013). Such rewards are considered to be the most salient influencers of salesperson's behavior (e.g. Cravens et al. 1993; John and Weitz 1989; Oliver and Anderson 1994; Roman et al. 2005). The sales area, where these effort-performance-reward relationships are especially salient, likely provided optimal conditions for utilizing the theory.

However, despite generally fruitful results produced by the expectancy theory in salesperson motivation (as well as in the general psychology domain), most studies could not provide clear predictions for salesperson motivation (Evans et al. 1982). Research in psychology demonstrated "a lack of support for the multiplicative nature of the theory's components" (Kanfer et al. 2017, 344) and suggested the use of individual constructs of expectancy, instrumentality, and valence (Van Eerde and Thierry 1996).

\section{Attribution theory}

One interesting alternative theoretical approach that has been used in salesperson motivation research is attribution theory (Badovick 1990). Attribution theory, originated by Fritz Heider (1958), became widespread in the salesperson motivation literature during 1980s and 1990s. Heider (1958) suggested that people make attributions about themselves and other people in a manner of "naïve psychologists." Subsequently, Weiner (1980) further applied attribution theory in the area of motivation as a means to understand why individuals they succeeded or failed at a task. Sujan $(1986,41)$ was among the first sales motivation researchers to utilize attribution theory explicitly because it "appears to afford benefits over the expectancy value framework... in understanding the motivation to work smarter". He argued that instead of measuring motivation indirectly through valences, instrumentalities, and expectancies (as it's done in expectancy theory), it should be conceptualized as behavioral intentions. Badovick (1990) found a strong support for attribution theory and concluded that it should be used in addition to expectancy theory when examining human motivation.

\section{Self-determination theory (SDT)}

Expectancy and attribution theories were dominant in sales research until around the turn of the century (Cadwallader et al. 2010). Drawing from a wider psychology domain, Keaveney 
and Nelson (1993) and then Pullins et al. (2000) took a different approach to measure intrinsic motivation by utilizing Deci and Ryan's (1985a) measure of causality orientation of autonomy within the SDT framework. SDT is a macro theory of human behavior, personality and well-being (Ryan 1995). It was developed by Edward Deci and Richard Ryan (Deci 1975; Deci and Ryan 1980, 1985b) and has been successfully applied in the area of work motivation (Gagne and Deci 2005). The basic assumption of the SDT is that humans are active organisms with innate tendency for growth, integration, and self-development, and that social environments and contexts can either facilitate and promote the growth and integration or disrupt and diminish it (Deci and Ryan 2002). This combination of inner resources and social contexts results in motivational states through the satisfaction (or frustration) of the three basic human needs: need for competence, need for autonomy, and need for relatedness (Gagne and Deci 2005). One of the most important advancements brought by the SDT is that it emphasized the importance of looking at different types of motivation (i.e. intrinsic and extrinsic) instead of treating it as a "unitary concept that varies primarily in amount" (Cadwallader et al. 2010, 221).

The emergence of the SDT in sales force research appears to be particularly timely considering the recent changes in the sales field. Specifically, changes in the dynamism of selling and the increasingly autonomous decision-making setting where salespeople are becoming almost "social scientists capable of analyzing lines of power and influence across blurring boundaries" (Jones et al. 2005, 108) all have created fitting foundations for the development of the SDT in sales domain. Hohenberg and Homburg (2016) successfully applied the SDT to examine the effect of financial and non-financial steering instruments on salesperson innovative-selling motivation and found a strong support for the SDT.

\section{Combining theories}

Several authors in our sample endeavored to combine two or more theories of motivation in an attempt to expand the present knowledge on the topic (e.g. job design theory and expectancy theory, Tyagi 1985c). Hohenberg and Homburg $(2016,117)$ concluded that "future research could investigate how different motivation theories, such as SDT and expectancy theory, can be integrated to create a more nuanced perspective on intercultural sales force steering". Integrating theories could in some cases prove challenging as different theories are based on different assumptions, constructs, and relationships. And our tradition in academia is to pit one theory against another in competition for best explanatory power. However, Stathakopoulos (1996) in his work on sales force control systems asserted that 
theories do not necessarily have to be construed as competing, but rather can be built on as complementary to one another.

\section{Key motivational measures used}

In keeping with the conceptual dominance of expectancy theory, many studies have empirically operationalized motivation in line with the expectancy model (e.g. Cron et al. 1988; Ingram et al. 1989; Tyagi 1985a; Tyagi 1985c).

A number of other publications employ more direct measures of IM and EM, while several measures capture the affective and cognitive orientations of IM and EM. Table 1 below presents a summary of the key motivational measures used.

Place Table 1 about here

In short, although motivation is measured in various ways, a trend is apparent nonetheless. Most IM scales largely incorporate both affective (task enjoyment) and cognitive (challenge seeking) orientations of IM, while the measurement of EM in most cases essentially captures the cognitive orientation only (compensation seeking), ignoring the affective orientation (recognition seeking). This is largely in line with the trends in a wider I/O psychology literature (Kanfer et al. 2017).

\section{Key methodologies employed}

Methodological trends within the salesperson motivation literature are in line with those in sales research in general (Asare et al. 2012; Williams and Plouffe 2007). That is, the field is largely dominated by quantitative methodology -- specifically survey research. The Figure 3 portrays the key methodologies employed within our pool of articles.

Within our pool, 51 articles out of 63 utilized some form of cross-sectional survey approach.

Place Figure 3 about here

\section{Salesperson motivation: drivers and outcomes}


The literature on salesperson motivation has been concerned largely with the drivers and outcomes of motivation (Pullins 2001). The following two sections are dedicated to the drivers and outcomes of IM and EM of salespeople, followed by a third section presenting a synergetic view of combining IM and EM of salespeople.

\section{Drivers of salesperson motivation}

Studies on the drivers of salesperson motivation can be largely grouped into (1) organizational level variables and (2) individual level variables. Organizational level variables include those such as job-related factors, organizational stress, and sales force control systems, while individual level variables include demographics (e.g., age and gender), personal feelings and emotions. Both sets of variables have been popular topics of analysis for sales researchers, and we begin with a discussion of organizational level variables.

\section{Organizational level variables}

The organizational variable of job importance has produced mixed results. For instance, job importance was found to be a strong predictor of both IM and EM (Tyagi 1985b) or only a mild predictor and only of EM (Tyagi 1982). Further to this, supervisory support was found to have a significant impact on salesperson EM (Tyagi 1985a, 1985c) and on salesperson IM (Jaramillo and Mulki 2008; Tyagi 1982), or no impact at all (Kemp et al. 2013). Positive working environment (Kemp et al. 2013), organizational identification (Tyagi 1982), and salesperson-brand relationship (Michel et al. 2015) were reported to enhance salesperson motivation.

In addition, a number of studies have examined the effect of sales job related factors vis-à-vis job design theory (Hackman and Oldham 1976). These findings reveal that organizational stress, emotional exhaustion, and role conflict and overload negatively impact both IM and EM (Kemp et al. 2013; Tyagi 1982, 1985a), with role overload having a far stronger effect on IM rather than on EM and role ambiguity having no significant effect on either IM or EM (Tyagi 1985a). In line with wider research on organizational stress (e.g. Everly and Girdano 1980; Selye 1978; Singh 1998), moderate levels of stress were reported to be beneficial to enhancing salesperson motivation, whereas high levels of stress are detrimental to it (Tyagi 1985a).

An array of studies has examined the effect of sales force control systems on salesperson motivation, and Oliver and Anderson (1994) were pioneers in this field. They report that sales force control systems are important drivers of salespeople's affective and motivational states. Specifically, behavior-based control was found to be linked with greater IM, whereas outcome-based control was linked with greater EM. Further to this, behavior 
activity control was found to play a negative moderating role in the relationship between the proportion of commission (in total compensation) and IM.

Miao and Evans (2012) further investigated this question and found that a combination of the capability and outcome-based control systems enhanced IM, but a combination of capability and activity control can decrease it. Further, Hohenberg and Homburg (2016) utilized an SDT approach (Ryan and Deci 2000b), and concluded that both behavior-based and outcome-based steering instruments can increase salesperson's autonomous (intrinsic) innovation-selling motivation and financial performance.

Miao et al. (2007) however found that disaggregating IM and EM into their cognitive and affective orientations led to more nuanced findings in terms of the effect of control systems. Specifically, activity (behavior-based) control was positively related to the affective orientation (recognition seeking) aspect of EM. In contrast capability (behavior-based) control was positively related to the cognitive orientation of EM (compensation seeking). In addition, they found that activity control mainly affects challenge seeking (the cognitive orientation of IM), whereas capability control mainly affects task enjoyment (the affective orientation of IM).

Research in psychology (see Kanfer et al. 2017 for summary) also highlights the importance of considering cognitive and affective processes of human motivation. Kanfer et al. (2017) conclude that historically, motivational theories have primarily concentrated on the cognitive side of motivation somewhat overlooking the affective motivational processes. However, psychological research over the last few decades has progressed into including affect and emotion into the studies on motivation, which offers directions for the future theory development in the field of motivation (Kanfer et al. 2017). In this light, including both affective and cognitive orientations when studying IM and EM of salespeople seems especially sound.

\section{Individual level variables}

Several individual level variables have been found to influence motivation. For instance, salesperson motivation may vary significantly depending on age/career stage (Cron et al. 1988). This can be explained by salespeople's differences in valence for rewards, and whether these rewards contribute to a sense of accomplishment and career development aimed at different career stages. When IM and EM are disaggregated into their affective and cognitive orientations, the findings are somewhat different. Specifically, the cognitive orientation of IM and EM changes throughout career stages, whereas the affective dimension of IM and EM does not (Miao et al. 2009). Motivational perceptions were also found to vary 
significantly across certain national cultures (Dubinsky et al. 1994). Finally, Fine and Pullins (1998) in their study of the mentor-protégée relationship discovered differences in motivational variables between men and women within this relationship, a finding with a potentially fruitful implication for future research.

Personal feelings and emotions also have been demonstrated to play an important role in salesperson motivation (Badovick 1990; Badovick et al. 1992; Verbeke et al. 2004). Badovick (1990) found that feelings of self-blame after a failure to complete a quota and feelings of satisfaction in performance after completing a quota have different effects on salesperson motivation. Verbeke et al. (2004) reported that feelings of pride were also found to be an important driver of motivation (Verbeke et al. 2004). Feelings of fulfilment and enjoyment of being instrumental to the customer (customer orientation) was found to have a direct positive impact on salesperson IM (Mallin and Pullins 2009). Finally, perceptions of fairness (perceptions of gaining or losing sales potential in a territory realignment context) were found to be a significant predictor of salesperson motivation (Smith et al. 2000); and satisfaction with territory design were reported to have a positive impact on salesperson IM (Grant et al. 2001).

\section{Outcomes of salesperson motivation}

Interestingly, outcomes of salesperson motivation have been somewhat less extensively studied than that of the drivers. Early research on motivation revealed highly inconsistent findings. Some studies report IM as a stronger predictor of performance outcomes, whereas other studies argue in favor of EM. Specifically, Oliver (1974) found IM to be a poor predictor of performance while extrinsic motivation was effective in predicting it. The author even suggested that IM might be dysfunctional in influencing performance. These conclusions found support in a study by Ingram et al. (1989), who also reported that IM did not impact performance (via effort) whereas EM had a significant impact. Contrary to this, Tyagi (1985c) found that IM had a stronger effect on work performance compared with EM, while Jaramillo and Mulki (2008) reported that IM had a positive impact on salesperson effort but EM had a negative impact.

More recent studies have demonstrated a pattern that was more in favor of IM, which is fundamentally consistent with findings on employee motivation in $\mathrm{I} / \mathrm{O}$ psychology literature. Specifically, Levin et al. (2012) found that both IM and EM had a positive impact on the intention to use (sales- and marketing-related) technology. Miao and Evans (2007) reported that although both IM and EM contribute to performance, salesperson IM results in higher levels of performance than EM. In particular, intrinsically motivated salespeople were 
more likely to practice adaptive selling which led to enhanced performance (Jaramillo et al. 2007; Pettijohn et al. 2002; Roman and Iacobucci 2010). They consider failures as a learning opportunity that helps them to improve in the future (Sujan 1986), which also implies an important performance consequence. IM was also found to increase job satisfaction (Grant et al. 2001; Low et al. 2001), which again is linked with performance.

Sujan (1986) using attribution theory found that IM led salespeople to attribute failures to poor strategies. This in turn motivated them to work smarter, which had a more important performance implication than EM. In contrast, EM led salespeople to attribute failures to insufficient effort, which in turn motivated them to work harder. Building on this, more recent studies have found that in comparison to IM, EM salespeople are more willing to work both smarter and harder (Jaramillo and Mulki 2008; Oliver and Anderson 1994), which in turn has important bottom line implications.

Research on motivation has also studied negative job outcomes, such as role conflict and ambiguity and burnout. IM has been found to reduce burnout, perceptions of role ambiguity and role conflict (Grant et al. 2001; Keaveney and Nelson 1993; Low et al. 2001), and also to contribute to a lessening in the tendency to engage in problematic behaviors (Murphy 2004). However, these findings may be seen in a different light when IM is further disaggregated into its orientations. For example, challenge seeking (IM), was found to decrease salesperson role conflict while task enjoyment (IM) was found to increase role ambiguity (Miao and Evans 2007; Miao et al. 2007). The two EM orientations have also been found to work in opposition. Specifically, compensation seeking (EM) was found to decrease role conflict, whereas recognition seeking (EM) was found to increase it (Miao and Evans 2007).

Finally, a number of studies have examined the relationship between salesperson motivation and job satisfaction. For instance, motivation for recognition (EM, affective) was found to have a direct positive effect on job satisfaction (Tanner et al. 2015). Miao and Evans (2014) found that the two extrinsic motivational orientations have different effects on job satisfaction depending on the proportion of new customers they are dealing with. Specifically, the authors demonstrated that compensation seeking (EM) enhanced job satisfaction only when salespeople were dealing with lower percentages of new customers, but recognition seeking (EM) enhanced job satisfaction when salespeople were dealing with higher percentages of new accounts. In tandem, compensation seeking (EM) led to higher levels of performance when salespeople dealt with more new customers, but the opposite was true for challenge seeking (IM). 


\section{Combining the types of salesperson motivation}

This literature on the outcomes of salesperson motivation demonstrates that IM is generally associated with higher levels of performance and other important salesperson job outcomes than EM. However, as later studies demonstrate, when IM and EM are disaggregated into the cognitive and affective orientations, the results do not appear to be solely in favor of IM. Moreover, in reality in most work situations people are motivated by both intrinsic and extrinsic motivators (Amabile 1993). Hence, examining a combined effect of IM and EM and their orientations would appear likely to produce more nuanced findings.

A limited number of studies on this subject exist in the sales domain, which primarily explore the effect of salesperson compensation (EM) on IM. For instance, Weitz et al. (1986) in their conceptual work proposed that the use of EM (incentive compensation) has a diminishing effect on IM orientation, especially if controlling rather than informational aspects of incentives are emphasized. Ingram and Bellenger (1983) found that salespeople on commission-based compensation plans (performance contingent extrinsic rewards) valued IM such as personal growth significantly higher than those salespeople on straight salary (performance non-contingent reward). Pullins (2001) has suggested that sales researchers should more vigorously investigate the impact of IM on salesperson EM.

\section{Key future research directions}

Based on the reviewed literature, we structure the future research directions into the following subcategories: (1) emerging trends and future research suggestions (digital technologies, team-based structures, salesperson ambidexterity, longitudinal research, and curvilinear relationships); (2) drivers of salesperson motivation; (3) outcomes of salesperson motivation; and (4) other important variables.

\section{Emerging trends and future research suggestions}

First, the emergence of innovative digital technologies, including social media (e.g., Linkedin, Twitter, Facebook), communication technologies (e.g., Skype, WebEx), cloudbased CRM technologies, mapping software, and apps has opened up new opportunities for the sales profession. These new digital technologies have paved the way to the era of big data (France and Ghose 2016) where large datasets of customer information are readily available. Salespeople can help in interpreting customer information, market trends, and identifying latent customer needs. However, working with big data implies a motivational challenge, as a salesperson's motivation is geared to the face-to-face encounter with the customers with focus on interpersonal communication skills such as presenting, negotiating, and listening. 
Prior studies have mainly relied on the Technology Readiness Index (Parasuraman 2000) and the Technology Acceptance Model (Venkatesh and Davis 2000) to examine the driving role of EM and IM factors to the adoption of traditional offline sales technologies. Compared to these traditional technologies, innovative digital technologies often are more complex and integrative in nature, requiring a broader scope and more profound intellectual effort from the salesperson. For instance, the use of cloud-based sales technologies (e.g. Womack 2017) and the integration of different types of information from different types of channels and actors implies a different and more demanding way of working that may disrupt existing selling routines. As a result, salespeople often are more hesitant to use these innovative digital technologies. Moreover, they may be afraid that adoption of the innovative technologies will lead to the automation of important aspects of their job activities and put their job at risk. Therefore, one major challenge concerns how to effectively motivate salespeople to adopt digital technologies and effectively operate in this transformative and changing context.

Second, the introduction of team and network-based structures (Stock 2006) has highlighted the importance of interpersonal dynamics as a key aspect of sales force motivation strategies. This underlines the importance of examining the role of team dynamics and interpersonal interactions with co-workers as drivers of salesperson motivation. The purpose of sales teams is having salespeople work together "to create synergies among team members with different levels of skills and experiences" (Ahearne et al. 2010, 461). The use of such team-based structures implies that salespeople should be motivated to fulfil an additional role of helping and supporting colleagues in their sales team. Yet, both academics and practitioners recognize the importance of properly balancing salespeople's motivation to effectively sell products and help colleagues on the team. This presents a challenge as many sales teams still are dominated by self-interest—where salespeople tend to focus on maximizing personal utility with little room for displaying prosocial behaviors, such as helping other colleagues in the team. More research is needed to examine how to adequately regulate salesperson motivation in team-based settings such that it yields a maximal result in terms of selling products and helping colleagues.

Future research could draw on the motivation, opportunity, and ability framework (MacInnis et al. 1991) to acquire more insight into salespeople's motivation to help colleagues and sell products by considering their ability and the emerging opportunity to help colleagues on the team. Furthermore, we recommend borrowing insights from literatures in social identity theory, social exchange theory, and social network theory to get better insight 
into the nature of salesperson motivation to sell in team-based structures (MacInnis et al. 1991; Schmitz 2013).

A related phenomenon is the emergence of global virtual sales teams (Badrinarayanan et al. 2011) and the use of groupware technology as a communication tool in those virtual teams (Janson et al. 2014). In a virtual context, it is more challenging to motivate salespeople, as managers have less capacity to control them. Then too, in a global virtual environment, clients may be doing business multiple time zones away and expect salespeople to be at their beckon call by virtual means during hours well outside the "normal work day" (Marshall et al. 2012).

Third, the traditional role of the salesperson is to carry out the different steps of the selling process, such as prospecting, approaching, negotiating, and closing the sale. However, the modern salesperson's job responsibilities have become much broader. Many salelspeople operate in a multi-task environments where they are engaged across greatly expended tasks and roles. In many modern companies salespeople have to go beyond the straightforward selling task and also perform marketing activities (Moncrief and Marshall 2005), combine the sale of products with the provision of high-quality customer service (Jasmand et al. 2012), or balance the traditional selling task with new selling approaches (der Borgh et al. 2015). Also, as mentioned earlier, team-based settings necessitate that salespeople combine additional prosocial behaviors such as helping colleagues with the gamut of selling responsibilities. Future research along these lines can make use of the literature on ambidexterity, which is the ability to combine potentially conflicting role activities to investigate how salespeople can successfully combine and integrate multiple roles (March 1991; Tushman and O'Reilly 1996). Other theoretical approaches that can yield better insights into how to effectively balance different roles in sales include role balance theory (Greenhaus et al. 2003; Marks and MacDermid 1996) and role theory (Katz and Kahn 1978). Role balance refers to the equal engagement of an individual in the performance of every role in his or her total role system (Marks and MacDermid 1996).

Another important emerging theory of motivation that can be fruitful in studying salesperson motivation is Vancouver's (2008) dynamic process theory of self-regulation. This theory incorporates both cognitive and affective processes by utilizing the notion of goal systems to understand a person's acting, thinking, learning, and feeling (Vancouver 2008). This is particularly relevant in sales roles when salespeople often work toward multiple goals. 
Fourth, there is a strong call for adapting longitudinal techniques in sales research to "gain a more nuanced understanding of many of the most commonly studied phenomena in our field" (Bolander et al. 2017). Researcher psychologists in the area of employee motivation assert that it is of crucial importance to adapt a dynamic interactionist approach to studying motivation in order to track how motivational variables change and develop over time (Kanfer et al. 2017). Advanced longitudinal techniques and multi-source data (e.g. as it was done by Fu et al. 2009) can assist in exploring the cause-and-effect dynamics of salesperson motivation over time and as such further strengthen and develop the theoretical framework of the domain (Bolander et al. 2017). Another approach is Steel and König's (2006) temporal motivation theory (TMT), which is grounded on the premises of expectancy theory, picoeconomics, cumulative prospect theory, and need theory. TMT strives to provide "unifying insights from several theories of motivation" (Steel and Konig 2006, 907). Importantly for sales research, it defines expectancy and valence in truly dynamic terms. It also incorporates time to deadlines as a predictor for subjective utility followed by task choices over time (Vancouver et al. 2010).

Finally, an interesting avenue for future research is to explore the possibility of curvilinear relationships (Walton 1969) between motivational and outcome (e.g. task performance, salesperson well-being, customer satisfaction) variables. For instance, a number of studies have found support for a presence of a U-shaped relationship between assigned goals and selling effort (Fang et al. 2004), quota levels and salesperson performance (Chowdhury 1993), and task conflict and employee creativity (De Dreu 2006). This raises the intriguing question: Is it possible to be too much motivated and is there a point of optimal level of motivation?

\section{Drivers of salesperson motivation}

Although sales motivation research to date has examined several drivers of salesperson motivation, there appears to be a scarcity of knowledge on certain types of drivers of salesperson motivation - such as monetary versus non-monetary rewards.

One of the key challenges faced by sales motivation researchers is the assessment of the role of EM rewards such as financial incentives on IM variables. Pullins (2001) summarized several propositions on this topic, most of which have not been addressed to date. Generally, extrinsic rewards have been found to have an undermining effect on IM, especially when such rewards are offered for highly interesting tasks and are contingent on performance (as summarised by Kanfer et al. 2017). It is known that sales compensation packages commonly consist of bonuses and commissions which are contingent to certain 
performance achievements (Kishore et al. 2013), hence these could be detrimental to IM. Mallin and Pullins (2009) found that sales force steering mechanisms (behavior activity control) negatively moderated the relationship between proportion of variable pay and IM. Careful utilization of the right (combination of) incentives as well as work environment contexts (e.g., sales force steering mechanisms) which would not harm IM but perhaps even enhance it appears to be critical in this light. Indeed, the most recent meta-analysis on this subject (Cerasoli et al. 2014), which included 40 years of research and nine previously published meta-analyses, has demonstrated that although extrinsic rewards (incentives) can undermine IM, in truth EM and IM can still co-exist. Future research could investigate how salespeople's motivational orientations might work in synergy (as proposed by Amabile 1993) by employing extrinsic rewards in such a way that they enhance IM.

Another key question is linked to non-monetary rewards. It has long been accepted that personal recognition, defined as "periodic acknowledgement of performance accomplishments of individual salespeople" (Wotruba et al. 1991, 9), is one of the important non-monetary rewards available to salespeople (Bellenger et al. 1984; Chonko et al. 1992; Churchill Jr et al. 1979). However, the current knowledge on the effect of such non-monetary rewards on salesperson IM and EM and performance is scarce. A potentially interesting research avenue lies in investigating the effect of non-monetary rewards on IM and EM as well as the combined effect of monetary incentives and non-monetary rewards on salesperson IM and EM and the four motivational orientations.

Finally, several studies within the sales domain have emphasized the importance of positive working environment and supervisory support in influencing salesperson behaviors (Jaramillo and Mulki 2008; Kemp et al. 2013; Tyagi 1982, 1985a, 1985b). These ideas are echoed in the organizational leadership literature (much of which is summarized by Bass and Stogdill 1990) which has demonstrated that charismatic leaders have highly motivated employees. However, how these influencers of motivation affect specific motivational orientations has not been explored to date. Hence, a potentially fruitful avenue for research is how sales leader behavior can influence the four motivational orientations.

\section{Outcomes of salesperson motivation}

To-date much of the research on outcomes of salesperson motivation is concerned with salesperson performance, for several good reasons. For example, the sales force typically accounts for the largest part of the marketing budget and marketing personnel (Cravens et al. 1993), hence their actual performance is of crucial prominence in terms of ROI. That is, sales organization performance has important direct bottom-line implications (MacKenzie et al. 
1998). However, contemporary research in other areas of the sales domain as well as in the wider marketing literature includes other types of job outcomes that are subjective or behavioral in nature. Examples include salesperson innovativeness and creativity (e.g. Bai et al. 2016; Miao and Wang 2016), work-life balance (e.g. Badrinarayanan et al. 2015; Closs et al. 2011) and work engagement (e.g. Fujimoto et al. 2016; Menguc et al. 2017). Such work outcomes are commonly found to have important implications for overall organizational development, customer orientation, job satisfaction, organizational commitment, and performance (e.g. Amabile 1996; Bai et al. 2016; Miao and Wang 2016; Schaufeli et al. 2002). Future research could benefit by incorporating more of these behavioral job outcomes into studies on salesperson IM and EM in order to gain a richer understanding of the consequences of salesperson motivation.

\section{Other important variables}

This article has emphasized that salesperson motivation research has gone from studying a global motivation construct to looking at IM and EM and to further disaggregating these into the cognitive and affective motivational orientations. Extant research findings suggest that these motivational orientations have distinct antecedents and consequences. Hence, an opportunity exists for future research to further examine the four motivational orientations, incorporating their drivers and outcomes at individual and organizational levels.

In addition, research demonstrates the importance of personality traits and personal characteristics of salespeople in the field of salesperson motivation. Chonko et al. (1992) suggested that salesperson personality traits and personal characteristics be taken into consideration when motivating salespeople. Indeed, B2B salespeople have been found to choose combinations of jobs and pay contracts that suit their heterogeneous traits (Lo et al. 2011). Further research on salesperson motivation could incorporate personality traits such as the "Big 5" into the research framework (e.g. the Big Five personality traits, He et al. 2015).

Research also demonstrates that motivational variables could differ for males versus female salespeople (e.g. Jaramillo and Mulki 2008). For instance, men and women were found to have differences in the ways motivational variables change across career stages (Cron et al. 1988) and in the motivational variables in the mentor-protégé relationship (Fine and Pullins 1998). More recent studies in sales have also demonstrated the importance of incorporating gender in sales force research (Rutherford et al. 2014). Boles et al. (2007) reported significant differences between male and female salespeople in the relationship between aspects of job satisfaction and affective organizational commitment. Rutherford et al. (2014) found that there are important gender effects in such areas of sales job as perceived 
organizational support, work-family conflict and emotional exhaustion. Finally, Karkoulian et al. (2016) in their study on work-life balance, perceived stress, and locus of control demonstrated the importance of this gender perspective. Future research investigating this matter in the sales context could offer fruitful insights on the topic of salesperson motivation, particularly since the percentage of females in B2B sales roles is rising.

\section{Conclusion}

The stated aim of our paper was to critically review the literature on salesperson motivation and, while presenting key theoretical and methodological contributions, to also highlight key challenges and future research directions. Although theory development has progressed in this area, and has generally become more nuanced in terms of insights presented by academic research into salesperson motivation, we find significant and new motivation-related challenges faced by sales organizations, sales managers and salespeople that are unexplored or underexplored in the literature. Without subsequent research by sales academics, it will be difficult to provide industry sales leaders credible advice on how to effectively motivate salespeople in light of these challenges. We assert that effort is required post haste in theory building and testing in salesperson motivation that can drive practical insights among the key areas identified within this article.

One of the main challenges to sales motivation research in particular is in "its ability to provide sales executives with actionable guidance" (Asare et al. 2012, 387). Hence, it is of crucial importance that sales motivation research remains current, in order to inform and help organizations address new and emerging challenges. Sales leaders and managers must become aware of different types of motivation, as well as their potential to work in synergy to increase important job outcomes. Early work on expectancy theory in sales changed the entire field of sales force management. Tut that was undertaken 30-40 years ago. We challenge today's generation of academic sales researchers to use this article as a springboard to develop the next generation of theory and practice in sales management, building on the history and opportunities revealed herein.

Motivating salespeople has always been one of the key challenges for sales leaders and, in truth, for firms as a whole. (Doyle and Shapiro 1980; Jaramillo et al. 2005). Recently such challenges have been amplified by significant challenges to how sales organizations have traditionally operated (Keszey and Biemans 2016). There have been dramatic shifts in the role of the salesperson, and the accompanying competencies required, due to a widening role often incorporating business development and internal business consultancy elements (Keszey and Biemans 2016; Narus 2015) coupled with seemingly ever-escalating 
requirements for a deep technological knowledge set (Marshall et al. 2012). Add to the above the fact that the race to deploy more virtual forms of salesperson/customer interaction and relationship management - often with a cost-cutting goal as the key driver (travel is expensive) -- has created challenges of workplace isolation for salespeople, both from their own company and their customers. This no doubt exacerbates the boundary-spanning role challenges and impacts motivation.

Then too, societal changes have presented key challenges as well, and in particular the arrival of millennials into the sales workforce with distinct professional work values and attitudes (Pullins et al. 2011). Indeed, recent research suggests that as millennials enter the workplace, organizations face additional and new motivational and retention-based challenges as initial evidence reveals millennials much more tuned into IM approaches versus EM (Ferri-Reed 2010). Our field must understand how to maximize salesperson success forward into the new horizons ahead. With hard work, we as sales academic researchers can build on our heritage of knowledge on salesperson motivation to open a new era of research discourse for the future of the field. 
Appendix. Summary table of key articles on salesperson motivation.

\begin{tabular}{|c|c|c|c|c|c|c|c|}
\hline $\mathbf{N}$ & Study & Journal & Methodology & $\begin{array}{l}\text { Sample size } \\
\text { and response } \\
\text { rate }\end{array}$ & Key relevant findings & Theory & $\begin{array}{l}\text { Summary on } \\
\text { motivation } \\
\text { measures. }\end{array}$ \\
\hline 1 & Oliver (1974) & JMR & $\begin{array}{l}\text { Cross-sectional } \\
\text { survey. }\end{array}$ & $95(96 \%)$ & $\begin{array}{l}\text { IM is a poor predictor of performance, whilst EM was } \\
\text { effective in predicting performance. }\end{array}$ & $\begin{array}{l}\text { Expectancy } \\
\text { theory. }\end{array}$ & $\begin{array}{l}\text { IM is measured } \\
\text { as five intrinsic } \\
\text { outcomes. }\end{array}$ \\
\hline 2 & $\begin{array}{l}\text { Walker et al. } \\
\text { (1977) }\end{array}$ & $\mathrm{JM}$ & $\begin{array}{l}\text { Conceptual } \\
\text { paper. }\end{array}$ & N/A & $\begin{array}{l}\text { The paper has provided a now classical definition: } \\
\text { "motivation is viewed as the amount of effort the salesman } \\
\text { desires to expend on each of the activities or tasks } \\
\text { associated with his job, such as calling on potential new } \\
\text { accounts, planning sales presentations, and filling out } \\
\text { reports". }\end{array}$ & $\begin{array}{l}\text { Expectancy } \\
\text { theory. }\end{array}$ & N/A. \\
\hline 3 & $\begin{array}{l}\text { Evans et al. } \\
(1982)\end{array}$ & JPSSM & $\begin{array}{l}\text { Literature } \\
\text { review. }\end{array}$ & N/A & $\begin{array}{l}\text { Literature review on expectancy theory research in sales } \\
\text { domain. }\end{array}$ & $\begin{array}{l}\text { Expectancy } \\
\text { theory. }\end{array}$ & N/A. \\
\hline 4 & Tyagi (1982) & JMR & $\begin{array}{l}\text { Cross-sectional } \\
\text { survey. }\end{array}$ & 104 & $\begin{array}{l}\text { IM and EM have distinct predictors (drivers) among the } \\
\text { organizational climate variables. Organizational climate } \\
\text { variables produce stronger influence on IM than on EM. All } \\
\text { organizational climate variables apart from challenge and } \\
\text { variety have a significant impact on IM (job importance, } \\
\text { Task conflict, Role overload, Leadership consideration, } \\
\text { Organizational identification and Management concern and } \\
\text { awareness). Job challenge and variety, job importance and } \\
\text { role overload do not significantly impact EM. Only job } \\
\text { importance and organizational identification have a mild } \\
\text { influence on EM. }\end{array}$ & $\begin{array}{l}\text { Expectancy } \\
\text { theory. }\end{array}$ & $\begin{array}{l}\text { Developed his } \\
\text { own in line with } \\
\text { Expectancy } \\
\text { model. }\end{array}$ \\
\hline 5 & $\begin{array}{l}\text { Becherer et } \\
\text { al. (1982) }\end{array}$ & $\mathrm{JM}$ & $\begin{array}{l}\text { Cross-sectional } \\
\text { survey. }\end{array}$ & $\begin{array}{l}214 \text { (33.2-65.8 } \\
\text { depending on } \\
\text { how many } \\
\text { questionnaires } \\
\text { have reached } \\
\text { the } \\
\text { salespeople) }\end{array}$ & $\begin{array}{l}\text { Job related factors impact on motivation and job satisfaction } \\
\text { of salespeople. It appears that internal motivation is } \\
\text { positively related to the ways salespeople perceive their job } \\
\text { characteristics and psychological states. }\end{array}$ & $\begin{array}{l}\text { Job design } \\
\text { theory. }\end{array}$ & $\begin{array}{l}\text { Job diagnostics } \\
\text { survey by } \\
\text { Hackman and } \\
\text { Oldham (1974). }\end{array}$ \\
\hline
\end{tabular}




\begin{tabular}{|c|c|c|c|c|c|c|c|}
\hline 6 & $\begin{array}{l}\text { Churchill et } \\
\text { al. (1985) }\end{array}$ & JMR & Meta-analysis. & N/A & $\begin{array}{l}\text { Motivation is third most important determinant of } \\
\text { performance. }\end{array}$ & N/A & N/A \\
\hline 7 & $\begin{array}{l}\text { Tyagi } \\
(1985 a)\end{array}$ & JAMS & $\begin{array}{l}\text { Cross-sectional } \\
\text { survey. }\end{array}$ & $104(63 \%)$ & $\begin{array}{l}\text { Organizational stress variables contribute negatively to both } \\
\text { IM and EM. Role ambiguity did not produce any effect on } \\
\text { IM or EM, though this could be situational. Role conflict } \\
\text { was shown to produce the strongest negative impact on IM } \\
\text { and EM. The variable role overload had a much stronger } \\
\text { impact on IM than on EM. }\end{array}$ & $\begin{array}{l}\text { Expectancy } \\
\text { theory. }\end{array}$ & $\begin{array}{l}\text { Developed his } \\
\text { own. }\end{array}$ \\
\hline 8 & $\begin{array}{l}\text { Tyagi } \\
(1985 c)\end{array}$ & $\mathrm{JM}$ & $\begin{array}{l}\text { Cross-sectional } \\
\text { survey. }\end{array}$ & $111(62 \%)$ & $\begin{array}{l}\text { Both job (re)design and leader's behavior affect salesperson } \\
\text { IM and EM but to a different extent. Specifically, key job } \\
\text { dimensions (job autonomy, variety, importance, task } \\
\text { identity, feedback and agent's feedback) are more effective } \\
\text { in impacting IM whereas leadership behavior is more } \\
\text { effective in impacting EM. IM is more important predictor } \\
\text { of salesperson performance, than EM. }\end{array}$ & $\begin{array}{l}\text { Job design } \\
\text { theory and } \\
\text { expectancy } \\
\text { theory. }\end{array}$ & $\begin{array}{l}\text { Developed his } \\
\text { own. }\end{array}$ \\
\hline 9 & Sujan (1986) & JMR & $\begin{array}{l}\text { Cross-sectional } \\
\text { survey. }\end{array}$ & $1283(32 \%)$ & $\begin{array}{l}\text { Salespeople's motivation to work smarter has more } \\
\text { important performance implica tions that motivation to } \\
\text { work harder. An orie ntation towards extrinsic re wa rds } \\
\text { le ads salespeople to attribute their failures to a lack of } \\
\text { effort which in turn motivates them to work harder. An } \\
\text { orientation towards intrinsic rewards leads salespeople to } \\
\text { attribute failures to poor strategies which in turn motivates } \\
\text { them to work smarter. }\end{array}$ & $\begin{array}{l}\text { Attribution } \\
\text { theory. }\end{array}$ & $\begin{array}{l}\text { Developed his } \\
\text { own (M). }\end{array}$ \\
\hline 10 & $\begin{array}{l}\text { Teas and } \\
\text { McElroy } \\
(1986)\end{array}$ & JM & $\begin{array}{l}\text { Cross-sectional } \\
\text { survey. }\end{array}$ & N/A & The authors integrate expectancy and attribution theory. & $\begin{array}{l}\text { Expectancy } \\
\text { theory and } \\
\text { attribution } \\
\text { theory. }\end{array}$ & N/A. \\
\hline 11 & $\begin{array}{l}\text { Weitz et al. } \\
(1986)\end{array}$ & $\mathrm{JM}$ & $\begin{array}{l}\text { Cross-sectional } \\
\text { survey. }\end{array}$ & N/A & $\begin{array}{l}\text { The authors propose a framework for motivation to practice } \\
\text { adaptive selling. }\end{array}$ & $\begin{array}{l}\text { Attribution } \\
\text { theory and } \\
\text { theory Z. }\end{array}$ & N/A. \\
\hline 12 & $\begin{array}{l}\text { Beltramini } \\
\text { and Evans } \\
(1988)\end{array}$ & JPSSM & $\begin{array}{l}\text { Cross-sectional } \\
\text { survey. }\end{array}$ & $933(46.7 \%)$ & $\begin{array}{l}\text { Contests have a potential to motivate salespeople, however, } \\
\text { in order to serve a motivating purpose, they should be } \\
\text { perceived as separate from the main compensation. }\end{array}$ & Not specified. & $\begin{array}{l}\text { A series of } \\
\text { agree/disagree } \\
\text { items adapted }\end{array}$ \\
\hline
\end{tabular}




\begin{tabular}{|c|c|c|c|c|c|c|c|}
\hline & & & & & & & $\begin{array}{l}\text { from Churchill et } \\
\text { al. (1974). }\end{array}$ \\
\hline 13 & $\begin{array}{l}\text { Cron et al. } \\
(1988)\end{array}$ & JM & $\begin{array}{l}\text { Cross-sectional } \\
\text { survey. }\end{array}$ & $176(78 \%)$ & $\begin{array}{l}\text { Salesperson motivation varies depending on career stage - in } \\
\text { line with career stages framework. }\end{array}$ & $\begin{array}{l}\text { Expectancy } \\
\text { theory. }\end{array}$ & $\begin{array}{l}\text { Used } \\
\text { thermometer like } \\
\text { scales and } \\
\text { chances } 0 \text { to } 100 \\
\text { on the } \\
\text { expectancy, } \\
\text { valence and } \\
\text { instrumentality. }\end{array}$ \\
\hline 14 & $\begin{array}{l}\text { Abratt and } \\
\text { Smythe } \\
\text { (1989) }\end{array}$ & IMM & $\begin{array}{l}\text { Cross-sectional } \\
\text { survey. }\end{array}$ & $\begin{array}{l}\text { Study of } 75 \\
\text { industrial firms } \\
\text { in South } \\
\text { Africa. }\end{array}$ & $\begin{array}{l}\text { The key salesperson motivators are satisfaction in the job } \\
\text { well done and a desire for money. }\end{array}$ & Not specified. & N/A. \\
\hline 15 & $\begin{array}{l}\text { Ingram et al. } \\
(1989)\end{array}$ & JPSSM & $\begin{array}{l}\text { Cross-sectional } \\
\text { survey. }\end{array}$ & $231(57.5 \%)$ & $\begin{array}{l}\text { Salesperson's EM but not IM has a significant positive } \\
\text { influence on effort which in turn has a significant positive } \\
\text { influence on performance. }\end{array}$ & $\begin{array}{l}\text { Expectancy } \\
\text { theory. }\end{array}$ & $\begin{array}{l}\text { Tyagi }(1985 \mathrm{c}) \\
\text { and Kohli } \\
(1985) \text {. }\end{array}$ \\
\hline 16 & $\begin{array}{l}\text { Badovick } \\
(1990)\end{array}$ & JAMS & $\begin{array}{l}\text { Cross-sectional } \\
\text { survey. }\end{array}$ & $\begin{array}{l}146(94 \%) \\
\text { respondents } \\
\text { who failed to } \\
\text { make their } \\
\text { monthly quota }\end{array}$ & $\begin{array}{l}\text { Attribution theory is proposed as an additional theory of } \\
\text { salesperson motivation. Feelings of self-blame after a failure } \\
\text { of not completing a quota and feeling of satisfaction in } \\
\text { performance (after completing a quota) directly influence } \\
\text { motivation. When salesperson takes responsibility for their } \\
\text { performance, then feelings of self-blame result in increased } \\
\text { subsequent effort. Contrary to Weiner's Attribution theory, } \\
\text { feelings of performance satisfaction resulted in subsequent } \\
\text { decrease in effort. }\end{array}$ & $\begin{array}{l}\text { Attribution } \\
\text { theory. }\end{array}$ & $\begin{array}{l}\text { Sujan's (1986) } \\
\text { Smarter and } \\
\text { harder. }\end{array}$ \\
\hline 17 & $\begin{array}{l}\text { Spiro and } \\
\text { Weitz (1990) }\end{array}$ & JMR & $\begin{array}{l}\text { Cross-sectional } \\
\text { survey (scale } \\
\text { development). }\end{array}$ & $268(54 \%)$ & $\begin{array}{l}\text { Scale development. } \\
\text { IM is a part of the developed adaptive selling framework } \\
\text { and measured as rewards arising from the task itself (e.g., } \\
\text { selling is like playing a game). }\end{array}$ & Not specified. & $\begin{array}{l}\text { Developed their } \\
\text { own (IM). }\end{array}$ \\
\hline 18 & $\begin{array}{l}\text { Chonko et al. } \\
(1992)\end{array}$ & JPSSM & $\begin{array}{l}\text { Cross-sectional } \\
\text { survey. }\end{array}$ & $249(24.9 \%)$ & $\begin{array}{l}\text { Sales people report that pay rises are one of the most } \\
\text { important motivators. }\end{array}$ & Not specified. & N/A. \\
\hline
\end{tabular}




\begin{tabular}{|c|c|c|c|c|c|c|c|}
\hline 19 & $\begin{array}{l}\text { Chowdhury } \\
\text { (1993) }\end{array}$ & JMR & $\begin{array}{l}\text { Laboratory } \\
\text { experiments. }\end{array}$ & N/A & $\begin{array}{l}\text { Strong effect of self-efficacy on salesperson motivation and } \\
\text { effort when sales tasks begin to increase in difficulty. } \\
\text { However, this effect is only marginal for low quota levels or } \\
\text { for easy tasks. }\end{array}$ & $\begin{array}{l}\text { Expectancy } \\
\text { theory, } \\
\text { achievement } \\
\text { motivation } \\
\text { theory and goal } \\
\text { setting theory. }\end{array}$ & $\begin{array}{l}\text { Not measured. } \\
\text { Motivation is } \\
\text { used } \\
\text { interchangeably } \\
\text { with effort. }\end{array}$ \\
\hline 20 & $\begin{array}{l}\text { Dubinsky et } \\
\text { al. (1993) }\end{array}$ & JPSSM & $\begin{array}{l}\text { Cross-sectional } \\
\text { survey. }\end{array}$ & $212(62 \%)$ & $\begin{array}{l}\text { Minimal differences in male and female salespeople's } \\
\text { perceptions of expectancies, instrumentalities, and valence } \\
\text { for rewards. }\end{array}$ & $\begin{array}{l}\text { Expectancy } \\
\text { theory. }\end{array}$ & $\begin{array}{l}\text { Teas (1981) and } \\
\text { Tyagi (1985a). }\end{array}$ \\
\hline 21 & $\begin{array}{l}\text { Keaveney } \\
\text { and Nelson } \\
(1993)\end{array}$ & JAMS & $\begin{array}{l}\text { Cross-sectional } \\
\text { survey. }\end{array}$ & $305(43.6)$ & $\begin{array}{l}\text { Intrinsic motivational orientations decrease perceptions of } \\
\text { role conflict and role ambiguity and enhance job } \\
\text { satisfaction. }\end{array}$ & $\begin{array}{l}\text { Causality } \\
\text { orientations } \\
\text { theory (SDT). }\end{array}$ & $\begin{array}{l}\text { Developed their } \\
\text { own (guided by } \\
\text { Ryan and Deci } \\
\text { (1985). }\end{array}$ \\
\hline 22 & $\begin{array}{l}\text { Dubinsky et } \\
\text { al. (1994) }\end{array}$ & JBR & $\begin{array}{l}\text { Cross-sectional } \\
\text { survey. }\end{array}$ & $\begin{array}{l}218(64.1 \%) \\
220(62.9 \%) \\
\text { and } 156 \\
(34.7 \%)\end{array}$ & $\begin{array}{l}\text { Dramatic difference in motivational perceptions between the } \\
\text { US salespeople and Japanese and Korean salespeople. }\end{array}$ & $\begin{array}{l}\text { Expectancy } \\
\text { theory. }\end{array}$ & \\
\hline 23 & $\begin{array}{l}\text { Oliver and } \\
\text { Anderson } \\
(1994)\end{array}$ & JM & $\begin{array}{l}\text { Cross-sectional } \\
\text { survey. Dyadic } \\
\text { data from sales } \\
\text { managers and } \\
\text { salespeople. }\end{array}$ & $347(64 \%)$ & $\begin{array}{l}\text { Control systems influence salespeople's affective and } \\
\text { motivational states. Specifically, behavior-based control is } \\
\text { linked with greater IM, whereas outcome-based control is } \\
\text { linked with EM. }\end{array}$ & $\begin{array}{l}\text { Sales force } \\
\text { control } \\
\text { framework. }\end{array}$ & $\begin{array}{l}\text { Developed their } \\
\text { own (IM and } \\
\text { EM). }\end{array}$ \\
\hline 24 & $\begin{array}{l}\text { Keck et al. } \\
(1995)\end{array}$ & JPSSM & $\begin{array}{l}\text { In-depth } \\
\text { interviews and } \\
\text { cross-sectional } \\
\text { survey. }\end{array}$ & $92(64.6 \%)$ & $\begin{array}{l}\text { Motivation to earn money, personal enjoyment of selling, } \\
\text { motivation to earn recognition from the peers and } \\
\text { willingness to work hard are among several key agency } \\
\text { success factors. }\end{array}$ & Not specified. & N/A. \\
\hline 25 & $\begin{array}{l}\text { Barling et al. } \\
(1996)\end{array}$ & JAP & $\begin{array}{l}\text { Cross-sectional } \\
\text { survey }\end{array}$ & $105(87.5 \%)$ & $\begin{array}{l}\text { The time-management behavior varies across individual } \\
\text { levels of motivation. }\end{array}$ & Not specified. & $\begin{array}{l}\text { Spence et al. } \\
(1987) \\
\text { (achievement } \\
\text { striving). }\end{array}$ \\
\hline
\end{tabular}




\begin{tabular}{|c|c|c|c|c|c|c|c|}
\hline 26 & $\begin{array}{l}\text { DeCarlo et } \\
\text { al. (1997) }\end{array}$ & JPSSM & $\begin{array}{l}\text { Cross-sectional } \\
\text { survey. }\end{array}$ & $135(87 \%)$ & $\begin{array}{l}\text { Organizational support attributions following high self- } \\
\text { ratings can increase salesperson motivation, whereas } \\
\text { organizational support attributions following low } \\
\text { performance self-ratings can decrease it. }\end{array}$ & $\begin{array}{l}\text { Attribution } \\
\text { theory and } \\
\text { expectancy } \\
\text { theory. }\end{array}$ & N/A \\
\hline 27 & $\begin{array}{l}\text { Fine and } \\
\text { Pullins } \\
(1998)\end{array}$ & JPSSM & $\begin{array}{l}\text { Cross-sectional } \\
\text { survey. }\end{array}$ & $165(36.6 \%)$ & $\begin{array}{l}\text { Significant differences on motivational variables between } \\
\text { men and women in the mentor-protégé re lationship. } \\
\text { Specifically, female proté gés with fe male mentors } \\
\text { report higher motivation levels than male mentors with } \\
\text { female protégés. }\end{array}$ & Not specified. & $\begin{array}{l}\text { Hackman and } \\
\text { Oldham (1976). }\end{array}$ \\
\hline 28 & $\begin{array}{l}\text { Schulman } \\
(1999)\end{array}$ & JPSSM & $\begin{array}{l}\text { Conceptual } \\
\text { paper. }\end{array}$ & N/A & $\begin{array}{l}\text { Based on prior research, the authors conclude that optimism } \\
\text { result in increased level of motivation. }\end{array}$ & $\begin{array}{l}\text { Learned } \\
\text { helplessness } \\
\text { theory. }\end{array}$ & N/A. \\
\hline 29 & $\begin{array}{l}\text { Smith et al. } \\
(2000)\end{array}$ & JPSSM & $\begin{array}{l}\text { Cross-sectional } \\
\text { survey for study } \\
1 \text { and scenario- } \\
\text { based } \\
\text { experiment for } \\
\text { study } 2 \text {. }\end{array}$ & $\begin{array}{l}161(43 \%) \text { for } \\
\text { study } 1 \text { and } \\
251(31 \%) \text { for } \\
\text { study } 2\end{array}$ & $\begin{array}{l}\text { Perceptions of fairness (perceptions of gaining or loosing } \\
\text { sales potential) in territory-alignment situations affect } \\
\text { motivation. Salesperson motivation increases as managers } \\
\text { take more actions (justice/fairness related). } \\
\text { Motivation is an important predictor of performance. }\end{array}$ & $\begin{array}{l}\text { Expectancy } \\
\text { theory and } \\
\text { organizational } \\
\text { justice theory. }\end{array}$ & $\begin{array}{l}\text { Combination of } \\
\text { working hard } \\
\text { and working } \\
\text { smart measures } \\
\text { (Oliver and } \\
\text { Weitz, 1991 and } \\
\text { Sujan, Weitz and } \\
\text { Kumar, 1994). }\end{array}$ \\
\hline 30 & $\begin{array}{l}\text { Pullins et al. } \\
(2000)\end{array}$ & JBIM & $\begin{array}{l}\text { Laboratory } \\
\text { experiment. }\end{array}$ & 76 & $\begin{array}{l}\text { Individual differences in IM orientation (operationalized as } \\
\text { causality orientation of autonomy) affect the cooperative } \\
\text { negotiation tactics in negotiations between a seller and a } \\
\text { buyer. }\end{array}$ & SDT. & $\begin{array}{l}\text { Deci and Ryan's } \\
(1985) \text { general } \\
\text { causality } \\
\text { orientation scale. } \\
\text { SDT. }\end{array}$ \\
\hline 31 & $\begin{array}{l}\text { Grant et al. } \\
(2001)\end{array}$ & JAMS & $\begin{array}{l}\text { Cross-sectional } \\
\text { survey. }\end{array}$ & $148(55 \%)$ & $\begin{array}{l}\text { Satisfaction with territory design enhances IM which in turn } \\
\text { reduces role ambiguity. Also, IM increases job satisfaction. }\end{array}$ & Not specified & $\begin{array}{l}\text { Anderson and } \\
\text { Oliver (1987), } \\
\text { Oliver and } \\
\text { Anderson (1994) } \\
\text { and Cravens et } \\
\text { al. (1993) (IM). }\end{array}$ \\
\hline 32 & $\begin{array}{l}\text { Low et al. } \\
(2001)\end{array}$ & JM & $\begin{array}{l}\text { Cross-sectional } \\
\text { survey. }\end{array}$ & $148(55 \%)$ & $\begin{array}{l}\text { IM directly reduces burnout, role conflict, role ambiguity, } \\
\text { and increases job satisfaction. In turn, burnout has a } \\
\text { significant negative impact on job satisfaction and } \\
\text { performance. }\end{array}$ & Not specified. & $\begin{array}{l}\text { Anderson and } \\
\text { Oliver (1987), } \\
\text { Oliver and } \\
\text { Anderson (1994) }\end{array}$ \\
\hline
\end{tabular}




\begin{tabular}{|c|c|c|c|c|c|c|c|}
\hline & & & & & & & $\begin{array}{l}\text { and Cravens et } \\
\text { al. (1993) (IM). }\end{array}$ \\
\hline 33 & $\begin{array}{l}\text { Pullins } \\
(2001)\end{array}$ & IMM & Interviews. & 19 & $\begin{array}{l}\text { Managers think that less than half of the motivation comes } \\
\text { from incentive pay and the rest (biggest part) comes from } \\
\text { intrinsic rewards. }\end{array}$ & SDT. & N/A. \\
\hline 34 & $\begin{array}{l}\text { Dubinsky } \\
\text { and Skinner } \\
(2002)\end{array}$ & IMM & $\begin{array}{l}\text { Conceptual } \\
\text { paper. }\end{array}$ & N/A & $\begin{array}{l}\text { The authors build a proposition (among others) that } \\
\text { salesperson IM is positively related to discretionary effort. }\end{array}$ & $\begin{array}{l}\text { Expectancy } \\
\text { theory. }\end{array}$ & N/A. \\
\hline 35 & $\begin{array}{l}\text { Pettijohn et } \\
\text { al. }(2002)\end{array}$ & P\&M & $\begin{array}{l}\text { Cross-sectional } \\
\text { survey. }\end{array}$ & $109(50 \%)$ & $\begin{array}{l}\text { Interaction between salesperson motivation and skill level } \\
\text { significantly related to customer orientation levels. }\end{array}$ & Not specified. & N/A. \\
\hline 36 & $\begin{array}{l}\text { Menguc and } \\
\text { Barker } \\
(2003)\end{array}$ & JPSSM & $\begin{array}{l}\text { Cross-sectional } \\
\text { survey. }\end{array}$ & $102(20.7 \%)$ & $\begin{array}{l}\text { When extrinsic rewards (motivators) are strong, salespeople } \\
\text { may compensate for the lack of intrinsic rewards in their } \\
\text { jobs. }\end{array}$ & $\begin{array}{l}\text { Agency theory } \\
\text { and } \\
\text { organizational } \\
\text { control theory. }\end{array}$ & N/A. \\
\hline 37 & $\begin{array}{l}\text { Murphy } \\
(2004)\end{array}$ & JBR & $\begin{array}{l}\text { Cross-sectional } \\
\text { survey. }\end{array}$ & $827(53 \%)$ & $\begin{array}{l}\text { In high motivation conditions, affective organizational } \\
\text { commitment and relationship with supervisor lead to less } \\
\text { tendency to engage in problematic behaviors. }\end{array}$ & $\begin{array}{l}\text { Theory of } \\
\text { planned } \\
\text { behavior. }\end{array}$ & N/A. \\
\hline 38 & $\begin{array}{l}\text { Verbeke et } \\
\text { al. }(2004)\end{array}$ & JAMS & $\begin{array}{l}\text { Cross-sectional } \\
\text { survey (scenario } \\
\text { based). }\end{array}$ & $\begin{array}{l}93(30.5 \%) \text { in } \\
\text { study } 1 \text { and } \\
250(52 \%) \text { in } \\
\text { study } 2 .\end{array}$ & $\begin{array}{l}\text { Salespeople are affected by their emotions but they can } \\
\text { control them to their advantage. Specifically, pride was } \\
\text { found to stimulate performance-related motivations. }\end{array}$ & Not specified. & $\begin{array}{l}\text { Spiro and Weitz } \\
\text { (1990) and Sujan } \\
\text { (1994). }\end{array}$ \\
\hline 39 & $\begin{array}{l}\text { Brown et al. } \\
(2005)\end{array}$ & JPSSM & $\begin{array}{l}\text { Conceptual } \\
\text { paper. }\end{array}$ & & $\begin{array}{l}\text { Call for integrating the research domains of salesperson } \\
\text { motivation, control systems, and compensation. }\end{array}$ & N/A & $\begin{array}{l}\text { Goal theory and } \\
\text { expectancy } \\
\text { theory. }\end{array}$ \\
\hline 40 & $\begin{array}{l}\text { Harris et al. } \\
(2005)\end{array}$ & JAMS & $\begin{array}{l}\text { Cross-sectional } \\
\text { survey. }\end{array}$ & $190(84 \%)$ & $\begin{array}{l}\text { Learning orientation has a positive impact on customer } \\
\text { orientation, whereas performance orientation has a positive } \\
\text { impact on selling orientation. }\end{array}$ & Control theory. & N/A. \\
\hline
\end{tabular}




\begin{tabular}{|c|c|c|c|c|c|c|c|}
\hline 41 & $\begin{array}{l}\text { Segalla et al. } \\
(2006)\end{array}$ & IJRM & $\begin{array}{l}\text { Cross-sectional } \\
\text { survey (scenario } \\
\text { based) }\end{array}$ & $652(62 \%)$ & $\begin{array}{l}\text { Sales managers choose incentive pay to increase salesperson } \\
\text { motivation, or salary to increase control and parity. }\end{array}$ & $\begin{array}{l}\text { Expectancy } \\
\text { theory, agency } \\
\text { control theory } \\
\text { and social } \\
\text { comparison } \\
\text { theory. }\end{array}$ & N/A. \\
\hline 42 & $\begin{array}{l}\text { Jaramillo et } \\
\text { al. (2007) }\end{array}$ & JPSSM & $\begin{array}{l}\text { Cross-sectional } \\
\text { survey. }\end{array}$ & $400(66.7 \%)$ & $\begin{array}{l}\text { Initiative strengthens the positive relationship between IM } \\
\text { and adaptive selling. IM has a significant effect on adaptive } \\
\text { selling. Also, customer orientation mediates the relationship } \\
\text { between IM and adaptive selling. }\end{array}$ & $\begin{array}{l}\text { Action control } \\
\text { theory. }\end{array}$ & $\begin{array}{l}\text { Oliver and } \\
\text { Anderson (1994) } \\
\text { (IM and EM). }\end{array}$ \\
\hline 43 & $\begin{array}{l}\text { Miao et al. } \\
(2007)\end{array}$ & JBR & $\begin{array}{l}\text { Cross-sectional } \\
\text { survey. }\end{array}$ & $175(44.2 \%)$ & $\begin{array}{l}\text { Activity control primarily impacts challenge seeking (the } \\
\text { cognitive dimension of IM) and capability control mainly } \\
\text { affects task enjoyment (the affective dimension of IM). }\end{array}$ & SDT. & $\begin{array}{l}\text { Amabile et al } \\
\text { (1994). }\end{array}$ \\
\hline 44 & $\begin{array}{l}\text { Miao and } \\
\text { Evans (2007) }\end{array}$ & JPSSM & $\begin{array}{l}\text { Cross-sectional } \\
\text { survey. }\end{array}$ & $175(44.2 \%)$ & $\begin{array}{l}\text { Cognitive and affective orientations of IM and EM have } \\
\text { distinct impact on role conflict and role ambiguity and } \\
\text { subsequently, behavioral and outcome performance. }\end{array}$ & Not specified. & $\begin{array}{l}\text { Amabile et al } \\
\text { (1994). }\end{array}$ \\
\hline 45 & $\begin{array}{l}\text { Jaramillo and } \\
\text { Mulki (2008) }\end{array}$ & JPSSM & $\begin{array}{l}\text { Cross-sectional } \\
\text { survey. }\end{array}$ & $344(60 \%)$ & $\begin{array}{l}\text { Supportive leadership has a direct positive effect on IM. IM } \\
\text { is an important driver of salesperson effort. EM has a } \\
\text { negative effect of effort. Female salespeople are less } \\
\text { influenced by EM than male salespeople. }\end{array}$ & $\begin{array}{l}\text { Path goal } \\
\text { theory and } \\
\text { social } \\
\text { cognitive } \\
\text { theory. }\end{array}$ & $\begin{array}{l}\text { Oliver and } \\
\text { Anderson (1994) } \\
\text { (IM and EM). }\end{array}$ \\
\hline 46 & $\begin{array}{l}\text { Miao et al. } \\
(2009)\end{array}$ & JPSSM & $\begin{array}{l}\text { Cross-sectional } \\
\text { survey. }\end{array}$ & $175(44 \%)$ & $\begin{array}{l}\text { Cognitive orientations of IM and EM vary depending on } \\
\text { salesperson's career stage, whereas affective } \\
\text { orientations of IM and EM do not. }\end{array}$ & $\begin{array}{l}\text { Expectancy } \\
\text { theory and } \\
\text { career stage } \\
\text { theory. }\end{array}$ & $\begin{array}{l}\text { Amabile et al } \\
\text { (1994). }\end{array}$ \\
\hline 47 & $\begin{array}{l}\text { Fu et al. } \\
(2009)\end{array}$ & JPSSM & $\begin{array}{l}\text { Longitudinal } \\
\text { study. }\end{array}$ & $\begin{array}{l}143(17.9 \% \\
\text { final response } \\
\text { rate) }\end{array}$ & $\begin{array}{l}\text { The study indicates the importance of motivation hub (self- } \\
\text { set goals and self-efficacy) in influencing salesperson's } \\
\text { effort and new product sales. }\end{array}$ & $\begin{array}{l}\text { Goal-setting } \\
\text { theory. }\end{array}$ & $\begin{array}{l}\text { Self-reported } \\
\text { measures of self- } \\
\text { set goals and } \\
\text { self-efficacy. }\end{array}$ \\
\hline
\end{tabular}




\begin{tabular}{|c|c|c|c|c|c|c|c|}
\hline 48 & $\begin{array}{l}\text { Mallin and } \\
\text { Pullins } \\
\text { (2009) }\end{array}$ & IMM & $\begin{array}{l}\text { Cross-sectional } \\
\text { survey. }\end{array}$ & 275 & $\begin{array}{l}\text { Salesperson customer orientation has a direct positive } \\
\text { impact on IM through feelings of fulfilment and enjoyment } \\
\text { of being instrumental to the customer. } \\
\text { Behavior activity control negatively moderates the } \\
\text { relationship between the proportion of commission (in total } \\
\text { compensation) and IM. }\end{array}$ & $\begin{array}{l}\text { Cognitive } \\
\text { evaluation } \\
\text { theory (SDT). }\end{array}$ & $\begin{array}{l}\text { Oliver and } \\
\text { Anderson's } \\
(1994)(\mathrm{IM}) .\end{array}$ \\
\hline 49 & $\begin{array}{l}\text { Roman and } \\
\text { Iacobucci } \\
(2010)\end{array}$ & JAMS & $\begin{array}{l}\text { Dyad: cross- } \\
\text { sectional survey } \\
\text { with salespeople } \\
\text { plus telephone } \\
\text { interviews for } \\
\text { customers. }\end{array}$ & $\begin{array}{l}210 \\
\text { salespeople } \\
\text { (out of } 300) \\
\text { and } 630 \\
\text { customers }\end{array}$ & $\begin{array}{l}\text { IM among others mediates the relationship between a } \\
\text { salesperson's perception of the firm's customer } \\
\text { orientation and salesperson's adaptive selling } \\
\text { be ha vior. }\end{array}$ & $\begin{array}{l}\text { Expectancy } \\
\text { theory. }\end{array}$ & $\begin{array}{l}\text { Spiro and Weitz } \\
\text { (1990) (IM). }\end{array}$ \\
\hline 50 & $\begin{array}{l}\text { Cadwallader } \\
\text { et al. (2010) }\end{array}$ & JAMS & $\begin{array}{l}\text { Cross-sectional } \\
\text { survey. }\end{array}$ & $328(100 \%)$ & $\begin{array}{l}\text { The study incorporates three levels of motivation: global, } \\
\text { contextual, and situational (Vallerand 1995, 1997). Global } \\
\text { motivation positively impact on contextual motivation } \\
\text { regarding technology and work. Then, the contextual } \\
\text { motivation for both technology and work has a positive } \\
\text { impact on innovation implementation. Employee feelings } \\
\text { and beliefs have a significant impact on situational } \\
\text { motivation to implement service innovation strategies. }\end{array}$ & SDT. & $\begin{array}{l}\text { Guay et al } \\
(2000) \text {. }\end{array}$ \\
\hline 51 & $\begin{array}{l}\text { Byrne et al. } \\
(2011)\end{array}$ & IMM & $\begin{array}{l}\text { Interviews and } \\
\text { cross-sectional } \\
\text { survey. }\end{array}$ & $262(68.6 \%)$ & $\begin{array}{l}\text { Motivational dimensions of sales force forecasting } \\
\text { (satisfaction, seriousness and effort) are influenced by the } \\
\text { five environmental signals: training, feedback, knowledge of } \\
\text { how the forecast is used, forecasting computer program, and } \\
\text { others' level of seriousness. }\end{array}$ & $\begin{array}{l}\text { Developed } \\
\text { their own } \\
\text { (theory of } \\
\text { industrial sales } \\
\text { force } \\
\text { forecasting) }\end{array}$ & $\begin{array}{l}\text { Developed their } \\
\text { own (for } \\
\text { satisfaction, } \\
\text { seriousness and } \\
\text { effort) }\end{array}$ \\
\hline 52 & $\begin{array}{l}\text { Levin et al. } \\
(2012)\end{array}$ & JPSSM & $\begin{array}{l}\text { Quasi- } \\
\text { experiment. }\end{array}$ & $194(68.5 \%)$ & $\begin{array}{l}\text { IM and EM have a positive impact whereas apathetic } \\
\text { motivation has a negative impact on the intention to use } \\
\text { sales- and marketing-related technology. }\end{array}$ & Not specified & $\begin{array}{l}\text { Davis et al } \\
(1992) \text { (IM and } \\
\text { EM). Vallerand } \\
\text { et al (1992) } \\
\text { (apathetic } \\
\text { motivation) }\end{array}$ \\
\hline
\end{tabular}




\begin{tabular}{|c|c|c|c|c|c|c|c|}
\hline 53 & $\begin{array}{l}\text { Miao and } \\
\text { Evans (2012) }\end{array}$ & IJRM & $\begin{array}{l}\text { Cross-sectional } \\
\text { survey. }\end{array}$ & $\begin{array}{l}195 \\
\text { salesperson- } \\
\text { sales manager } \\
\text { dyads }(16.3- \\
19.2 \%)\end{array}$ & $\begin{array}{l}\text { The combination of capability and outcome-based control } \\
\text { systems has a positive combined effect on IM and } \\
\text { salesperson knowledge. The combination of outcome and } \\
\text { activity based control systems decrease IM but increase role } \\
\text { clarity. IM diminishes the negative effect of role ambiguity } \\
\text { on performance. }\end{array}$ & $\begin{array}{l}\text { Expectancy } \\
\text { theory and } \\
\text { Cognitive } \\
\text { evaluation } \\
\text { theory (SDT). }\end{array}$ & $\begin{array}{l}\text { IM and EM scale } \\
\text { was borrowed } \\
\text { from Miao et al. } \\
\text { (2007), though } \\
\text { EM is only a } \\
\text { control variable. }\end{array}$ \\
\hline 54 & $\begin{array}{l}\text { Kemp et al. } \\
(2013)\end{array}$ & EJM & $\begin{array}{l}\text { Cross-sectional } \\
\text { survey. }\end{array}$ & $154(51.3 \%)$ & $\begin{array}{l}\text { Salesperson motivation is positively related to positive } \\
\text { working environments and customer-oriented selling and } \\
\text { negatively related to emotional exhaustion. Also, the } \\
\text { relationship between manager support and salesperson } \\
\text { motivation was not significant. However, the experience of } \\
\text { positive emotions mediates the relationship between } \\
\text { managers' support and salesperson motivation. }\end{array}$ & Not specified. & $\begin{array}{l}\text { Badovick et al. } \\
\text { (1992). }\end{array}$ \\
\hline 55 & $\begin{array}{l}\text { Schmitz } \\
(2013)\end{array}$ & JAMS & $\begin{array}{l}\text { Cross-sectional } \\
\text { survey. }\end{array}$ & $\begin{array}{l}55 \text { usable } \\
\text { level-2 and } 222 \\
\text { usable level-1 } \\
\text { data records } \\
(77 \%)\end{array}$ & $\begin{array}{l}\text { The study found that the relationship between salesperson's } \\
\text { motivation and their adoption of the company's product } \\
\text { portfolio is pos itively moderated by a strong team group } \\
\text { norm for cross-selling. }\end{array}$ & $\begin{array}{l}\text { Social norm } \\
\text { theory and } \\
\text { reputation } \\
\text { theory. }\end{array}$ & $\begin{array}{l}\text { Sujan et al. } \\
1994 .\end{array}$ \\
\hline 56 & $\begin{array}{l}\text { Yidong and } \\
\text { Xinxin } \\
(2013)\end{array}$ & JBE & $\begin{array}{l}\text { Cross-sectional } \\
\text { survey. }\end{array}$ & $302(75.5 \%)$ & $\begin{array}{l}\text { IM mediates the relationship between the perceptions of } \\
\text { ethical leadership on an individual and group level and } \\
\text { salespeople's innovative work behavior. }\end{array}$ & $\begin{array}{l}\text { Cognitive } \\
\text { evaluation } \\
\text { theory (SDT). }\end{array}$ & $\begin{array}{l}\text { Zhang and } \\
\text { Bartol (2010). }\end{array}$ \\
\hline 57 & $\begin{array}{l}\text { Michel et al. } \\
\text { (2015) }\end{array}$ & JPSSM & $\begin{array}{l}\text { Interviews and } \\
\text { cross-sectional } \\
\text { survey. }\end{array}$ & $\begin{array}{l}72 \text { for } \\
\text { interviews and } \\
297 \text { for survey. }\end{array}$ & $\begin{array}{l}\text { Salesperson-brand relationship and brand affect have a } \\
\text { positive effect on salesperson motivation to sell. }\end{array}$ & $\begin{array}{l}\text { Consumer- } \\
\text { brand } \\
\text { relationship } \\
\text { theory. }\end{array}$ & $\begin{array}{l}\text { Spiro and Weitz } \\
\text { (1990). }\end{array}$ \\
\hline 58 & $\begin{array}{l}\text { Tanner et al. } \\
(2015)\end{array}$ & JPSSM & $\begin{array}{l}\text { Cross-sectional } \\
\text { survey. }\end{array}$ & $339(97 \%)$ & $\begin{array}{l}\text { The effect of motivation for compensation/motivation for } \\
\text { recognition on performance was non-significant. However, } \\
\text { motivation for recognition was found to have a direct } \\
\text { positive effect on satisfaction with moderating (weakening) } \\
\text { effect of ethical climate. }\end{array}$ & $\begin{array}{l}\text { Expectancy } \\
\text { theory and } \\
\text { social } \\
\text { cognition } \\
\text { theory. }\end{array}$ & $\begin{array}{l}\text { Chonko et al } \\
\text { (1996). }\end{array}$ \\
\hline
\end{tabular}




\begin{tabular}{|c|c|c|c|c|c|c|c|}
\hline 59 & $\begin{array}{l}\text { Bande et al. } \\
(2016)\end{array}$ & JBIM & $\begin{array}{l}\text { Cross-sectional } \\
\text { survey. }\end{array}$ & $145(96 \%)$ & $\begin{array}{l}\text { IM mediates the positive relationship between servant } \\
\text { leadership and salesperson adaptively and proactivity. } \\
\text { Outcome-based control system strengthens the positive } \\
\text { impact of servant leadership on IM. }\end{array}$ & $\begin{array}{l}\text { Cognitive } \\
\text { evaluation } \\
\text { theory (SDT). }\end{array}$ & $\begin{array}{l}\text { Cravens et al. } \\
\text { (1993) (IM. }\end{array}$ \\
\hline 60 & $\begin{array}{l}\text { Hansen and } \\
\text { Levin (2016) }\end{array}$ & JBR & $\begin{array}{l}\text { Cross-sectional } \\
\text { survey. }\end{array}$ & $210(30 \%)$ & $\begin{array}{l}\text { Apathetic motivation, IM and EM are distinct variables that } \\
\text { can co-exist. }\end{array}$ & $\begin{array}{l}\text { Expectancy } \\
\text { theory and } \\
\text { SDT. }\end{array}$ & $\begin{array}{l}\text { Levin et al } \\
\text { (2012) (IM, EM } \\
\text { and apathetic } \\
\text { motivation). }\end{array}$ \\
\hline 61 & $\begin{array}{l}\text { Hohenberg } \\
\text { and } \\
\text { Homburg } \\
(2016)\end{array}$ & JM & $\begin{array}{l}\text { Cross-sectional } \\
\text { survey. }\end{array}$ & $\begin{array}{l}471(76.7) \\
\text { from across } 38 \\
\text { countries }\end{array}$ & $\begin{array}{l}\text { In all cultures both behavior-based and outcome-based } \\
\text { steering instruments can increase salesperson's } \\
\text { a tonomous innovation-s elling motivation and the } \\
\text { financial performance of innovations. Individualism } \\
\text { strengthens the positive relationship between variable } \\
\text { compensation and financial innovation performance through } \\
\text { IM, but the power distance and uncertainty avoidance } \\
\text { weaken this relationship Study findings offer a strong } \\
\text { support for SDT. }\end{array}$ & SDT. & $\begin{array}{l}\text { Grant et al. } \\
\text { (2011) (IM). }\end{array}$ \\
\hline 62 & $\begin{array}{l}\text { Sok et al. } \\
(2016)\end{array}$ & IMM & $\begin{array}{l}\text { Cross-sectional } \\
\text { survey. }\end{array}$ & $239(44 \%)$ & $\begin{array}{l}\text { "Can do" and "reasons to" motivations impact salesperson } \\
\text { ambidexterity. }\end{array}$ & $\begin{array}{l}\text { Regulatory } \\
\text { mode theory } \\
\text { and SDT. }\end{array}$ & $\begin{array}{l}\text { Spence and } \\
\text { Robbins (1992) } \\
\text { ("Reasons to" } \\
\text { motivations), } \\
\text { Kruglanski et al } \\
\text { (2000) ("Can do" } \\
\text { motivations) }\end{array}$ \\
\hline 63 & $\begin{array}{l}\text { Fu et al. } \\
(2017)\end{array}$ & JMTP & $\begin{array}{l}\text { Cross-sectional } \\
\text { survey. }\end{array}$ & $136(68 \%)$ & $\begin{array}{l}\text { IM and EM positively impact affective brand commitment } \\
\text { which in turn has a positive impact on effort. } \\
\text { Though the relationship of affective brand commitment and } \\
\text { effort is significant only when both IM and self-efficacy are } \\
\text { high. } \\
\text { Non-significant relationship between EM and effort. EM has } \\
\text { a positive impact on affective brand commitment. }\end{array}$ & $\begin{array}{l}\text { Theory of } \\
\text { planned } \\
\text { behavior and } \\
\text { the motivation, } \\
\text { opportunity, } \\
\text { and ability } \\
\text { theory. }\end{array}$ & $\begin{array}{l}\text { Miao, Evans and } \\
\text { Zou (2007) (IM } \\
\text { and EM) }\end{array}$ \\
\hline
\end{tabular}


Table 1. Summary of the key motivational measures used.

\begin{tabular}{|l|l|l|}
\hline Literature stream & How motivation is measured & Examples \\
\hline Expectancy theory & $\begin{array}{l}\text { Multiplication of the expectancy scores } \\
\text { (effort-performance relationship), with } \\
\text { the product of instrumentality } \\
\text { (performance-reward relationship) and } \\
\text { valence (rewards-personal goals } \\
\text { relationship). }\end{array}$ & $\begin{array}{l}\text { Ingram et al. (1989); Tyagi (1985a); } \\
\text { Cron et al. (1988); Ingram et al. } \\
\text { (1989); Tyagi (1985a, 1985c). }\end{array}$ \\
\hline Attribution theory & $\begin{array}{l}\text { A combination of working harder } \\
\text { (EM) and smarter (IM). }\end{array}$ & $\begin{array}{l}\text { Sujan et al. (1994); Badovick (1990); } \\
\text { Schmitz (2013); Verbeke et al. } \\
\text { (2004). }\end{array}$ \\
\hline Control systems & $\begin{array}{l}\text { Internal (IM) versus external (EM) } \\
\text { motivations. }\end{array}$ & $\begin{array}{l}\text { Anderson and Oliver (1987); Oliver } \\
\text { and Anderson (1994); Jaramillo et al. } \\
\text { (2007). }\end{array}$ \\
\hline $\begin{array}{l}\text { Affective and } \\
\text { cognitive } \\
\text { orientations of IM } \\
\text { and EM }\end{array}$ & $\begin{array}{l}\text { Specifically use designated scales for } \\
\text { each of the four motivational } \\
\text { orientations (originally developed by } \\
\text { Amabile et al. 1994). }\end{array}$ & $\begin{array}{l}\text { Miao and Evans (2012); Miao et al. } \\
\text { (2007); Miao et al. (2009) }\end{array}$ \\
\hline
\end{tabular}


Figure 1. Key journals.

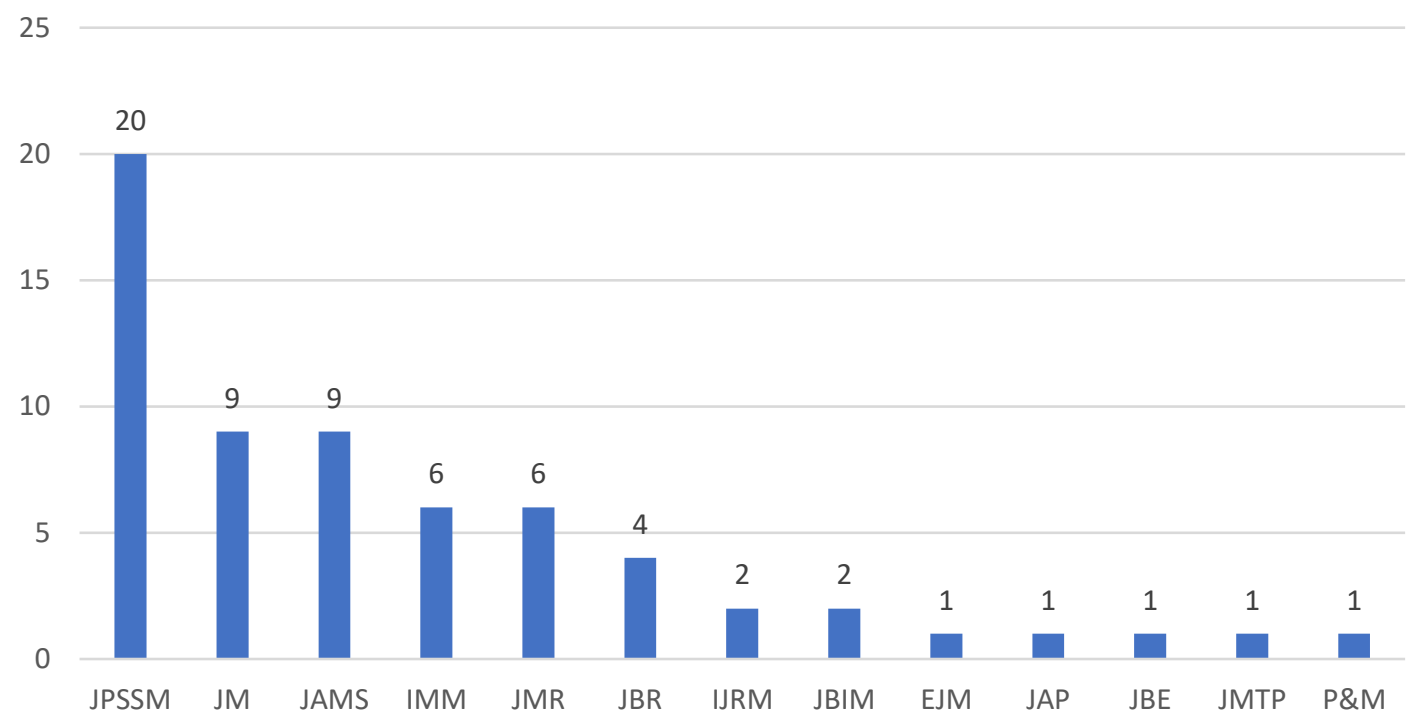


Figure 2. Key theories utilized.

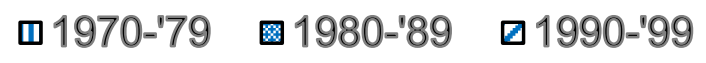

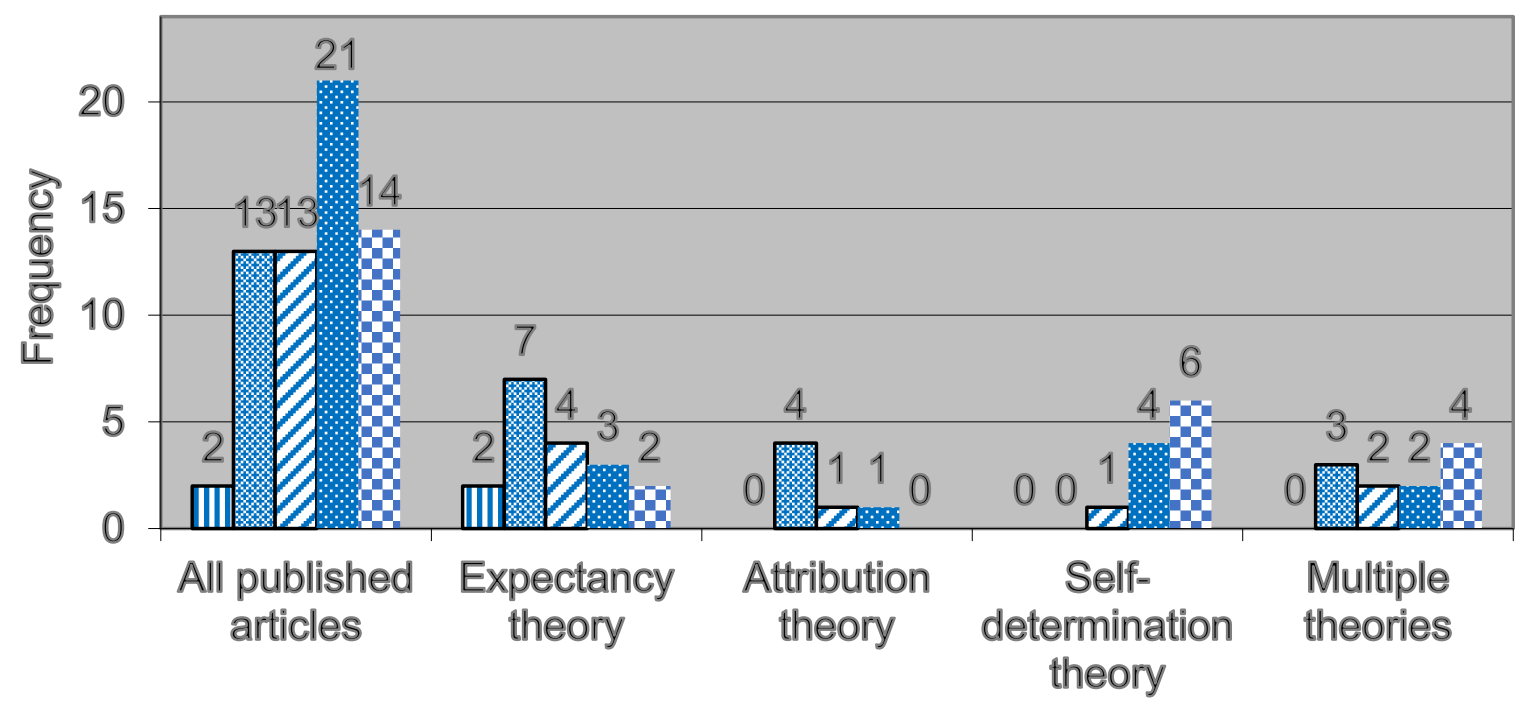


Figure 3. Key methodologies.

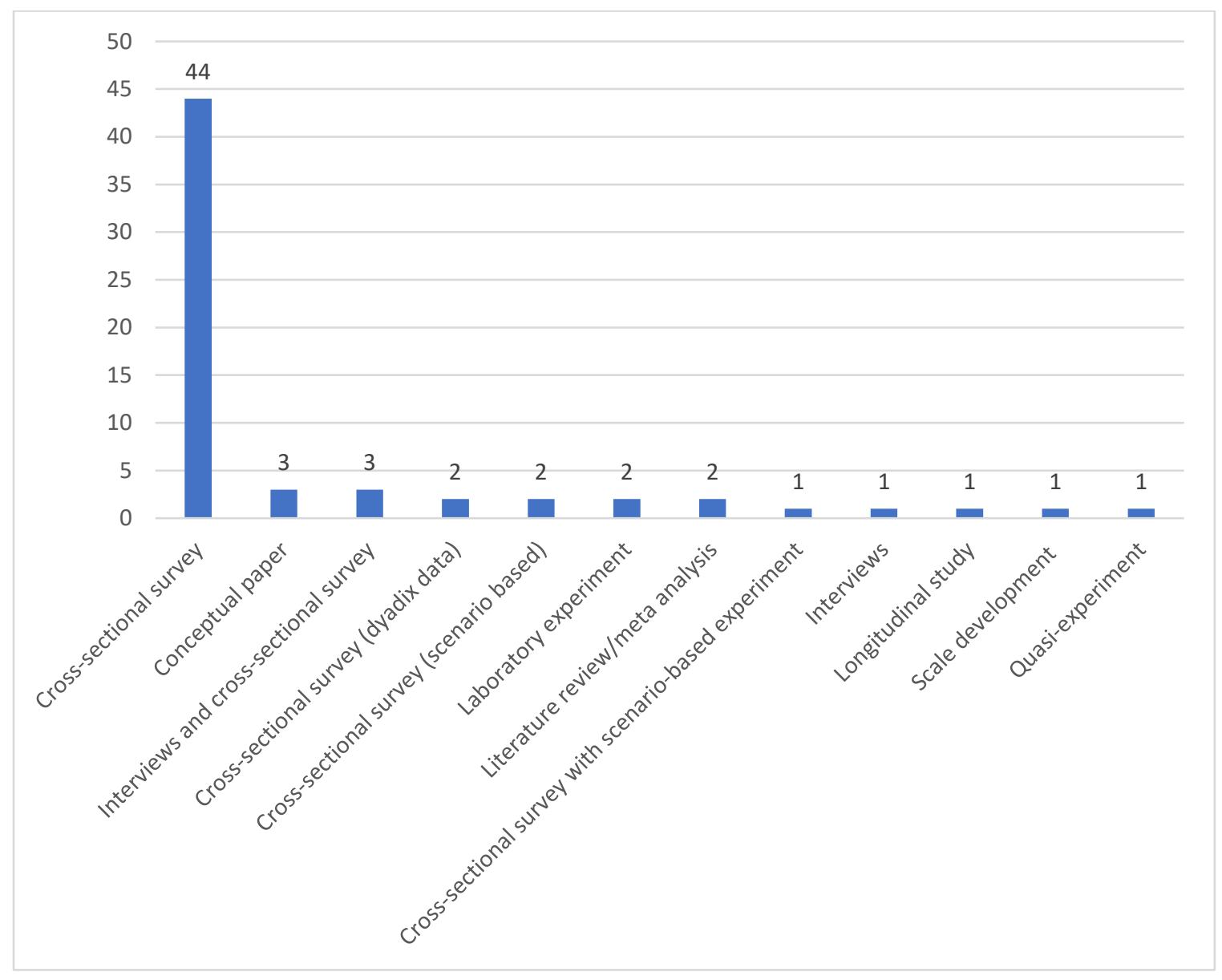




\section{References}

Abratt, Russell, and Smythe, Michael R. 1989. A Survey of Sales Incentive Programs. Industrial Marketing Management, 18(3), 209-214.

Ahearne, Michael, MacKenzie, Scott B., Podsakoff, Philip M., Mathieu, John E., and Lam, Son K. 2010. The Role of Consensus in Sales Team Performance. Journal of Marketing Research, 47(3), 458-469.

Alton, Larry. 2017. Millennials Are Changing the Way We Do Sales, and That's Having a Domino Effect on Our Workplace. Retrieved from Forbes website: https://www.forbes.com/sites/larryalton/2017/04/10/millennials-are-changing-theway-we-do-sales-and-thats-having-a-domino-effect-on-our-workplace/$6277 d 33 a 2124$

Amabile, Teresa M. 1993. Motivational Synergy: Toward New Conceptualizations of Intrinsic and Extrinsic Motivation in the Workplace. Human resource management review, 3(3), 185-201.

Amabile, Teresa M. 1996. Creativity and Innovation in Organizations: Harvard Business School.

Amabile, Teresa M, Hill, Karl G, Hennessey, Beth A, and Tighe, Elizabeth M. 1994. The Work Preference Inventory: Assessing Intrinsic and Extrinsic Motivational Orientations. Journal of personality and social psychology, 66(5).

Anders, George. 2012. For Lasting Sales Motivation, Stop Spraying Cash Around. Retrieved from Forbes website:

https://www.forbes.com/sites/georgeanders/2012/07/18/sales-pay-pink/ $11 \mathrm{~d} 6 \mathrm{ac} 447166$

Anderson, Erin, and Oliver, Richard L. 1987. Perspectives on Behavior-Based Versus Outcome-Based Salesforce Control Systems. The Journal of Marketing, 76-88.

Asare, Anthony K, Yang, Jing, and Alejandro, Thomas G Brashear. 2012. The State of Research Methods in Personal Selling and Sales Management Literature. Journal of Personal Selling and Sales Management, 32(4), 473-490.

Badovick, Gordon J. 1990. Emotional Reactions and Salesperson Motivation: An Attributional Approach Following Inadequate Sales Performance. Journal of the Academy of Marketing Science, 18(2), 123-130.

Badovick, Gordon J, Hadaway, Farrand J, and Kaminski, Peter F. 1992. Attributions and Emotions: The Effects on Salesperson Motivation after Successful Vs. Unsuccessful Quota Performance. The Journal of Personal Selling and Sales Management, 1-11.

Badrinarayanan, Vishag, Dixon, Andrea, West, Vicki L, and Zank, Gail M. 2015. Professional Sales Coaching: An Integrative Review and Research Agenda. European Journal of Marketing., 49(7/8), 1087-1113.

Badrinarayanan, Vishag, Madhavaram, Sreedhar, and Granot, Elad. 2011. Global Virtual Sales Teams (Gvsts): A Conceptual Framework of the Influence of Intellectual and Social Capital on Effectiveness. Journal of Personal Selling \& Sales Management, 31(3), 311-324.

Bai, Yuntao, Lin, Li, and Li, Peter Ping. 2016. How to Enable Employee Creativity in a Team Context: A Cross-Level Mediating Process of Transformational Leadership. Journal of Business Research, 69(9), 3240-3250.

Bande, Belén, Fernández-Ferrín, Pilar, Varela-Neira, Concepción, and Otero-Neira, Carmen. 2016. Exploring the Relationship among Servant Leadership, Intrinsic Motivation and 
Performance in an Industrial Sales Setting. Journal of Business \& Industrial Marketing, 31(2), 219-231.

Barczak, Gloria. 2017. Writing a Review Article. Journal of Product Innovation Management, 34(2), 120-121.

Barling, Julian, Cheung, Dominic, and Kelloway, E Kevin. 1996. Time Management and Achievement Striving Interact to Predict Car Sales Performance. Journal of Applied Psychology, 81(6), 821.

Bass, Bernard M, and Stogdill, Ralph Melvin. 1990. Bass \& Stogdill's Handbook of Leadership: Theory, Research, and Managerial Applications: Simon and Schuster.

Baumgartner, Hans, and Pieters, Rik. 2003. The Structural Influence of Marketing Journals: A Citation Analysis of the Discipline and Its Subareas over Time. Journal of Marketing, 67(2), 123-139.

Becherer, Richard C, Morgan, Fred W, and Richard, Lawrence M. 1982. The Job Characteristics of Industrial Salespersons: Relationship to Motivation and Satisfaction. The Journal of Marketing, 125-135.

Bellenger, Danny N, Wilcox, James B, and Ingram, Thomas N. 1984. An Examination of Reward Preferences for Sales Managers. Journal of Personal Selling \& Sales Management, 4(2), 1-6.

Beltramini, Richard F, and Evans, Kenneth R. 1988. Salesperson Motivation to Perform and Job Satisfaction: A Sales Contest Participant Perspective. The Journal of Personal Selling and Sales Management, 35-42.

Bolander, Willy, Dugan, Riley, and Jones, Eli. 2017. Time, Change, and Longitudinally Emergent Conditions: Understanding and Applying Longitudinal Growth Modeling in Sales Research. Journal of Personal Selling \& Sales Management, 1-17.

Boles, James, Madupalli, Ramana, Rutherford, Brian, and Andy Wood, John. 2007. The Relationship of Facets of Salesperson Job Satisfaction with Affective Organizational Commitment. Journal of Business \& Industrial Marketing, 22(5), 311-321.

Brack, Jessica, and Kelly, Kip. 2012. Maximizing Millennials in the Workplace. UNC Executive Development, 1-14.

Brown, Steven P, Evans, Kenneth R, Mantrala, Murali K, and Challagalla, Goutam. 2005. Adapting Motivation, Control, and Compensation Research to a New Environment. Journal of Personal Selling and Sales Management, 25(2), 156-167.

Byrne, Teresa M McCarthy, Moon, Mark A, and Mentzer, John T. 2011. Motivating the Industrial Sales Force in the Sales Forecasting Process. Industrial Marketing Management, 40(1), 128-138.

Cadwallader, Susan, Jarvis, Cheryl Burke, Bitner, Mary Jo, and Ostrom, Amy L. 2010. Frontline Employee Motivation to Participate in Service Innovation Implementation. Journal of the Academy of Marketing Science, 38(2), 219-239.

Cerasoli, Christopher P, Nicklin, Jessica M, and Ford, Michael T. 2014. Intrinsic Motivation and Extrinsic Incentives Jointly Predict Performance: A 40-Year Meta-Analysis. Psychological bulletin, 140(4), 980.

Cespedes, Frank V. , and Wallace, Christopher 2017. Executives and Salespeople Are Misaligned - and the Affects Are Costly. Retrieved from Harvard Business Review website: https://hbr.org/2017/01/executives-and-salespeople-are-misaligned-andthe-effects-are-costly 
Chonko, Lawrence B, Tanner Jr, John F, and Weeks, William A. 1992. Selling and Sales Management in Action: Reward Preferences of Salespeople. The Journal of Personal Selling and Sales Management, 67-75.

Chonko, Lawrence B, Tanner Jr, John F, and Weeks, William A. 1996. Ethics in Salesperson Decision Making: A Synthesis of Research Approaches and an Extension of the Scenario Method. Journal of Personal Selling \& Sales Management, 16(1), 35-52.

Chowdhury, Jhinuk. 1993. The Motivational Impact of Sales Quotas on Effort. Journal of Marketing Research, 30(1), 28.

Chung, Doug J. , and Narayandas, Das 2017. Study: More Frequent Sales Quotas Help Volume but Hurt Profits. Retrieved from Harvard Business Review website: https://hbr.org/2017/08/study-more-frequent-sales-quotas-help-volume-but-hurtprofits

Churchill, Gilbert A, Ford, Neil M, Hartley, Steven W, and Walker, Orville C. 1985. The Determinants of Salesperson Performance: A Meta-Analysis. Journal of Marketing Research, 103-118.

Churchill, Gilbert A, Ford, Neil M, and Walker, Orville C. 1974. Measuring the Job Satisfaction of Industrial Salesmen. Journal of Marketing Research, 254-260.

Churchill, Gilbert A, Ford, Neil M, and Walker, Orville C. 1976. Motivating the Industrial Salesforce: The Attractiveness of Alternative Rewards: Graduate School of Business, University of Wisconsin-Madison.

Churchill Jr, Gilbert A., Ford, Neil M., and Walker Jr, Orville C. 1979. Personal Characteristics of Salespeople and the Attractiveness of Alternative Rewards. Journal of Business Research, 7(1), 25-50.

Closs, David J, Speier, Cheri, and Meacham, Nathan. 2011. Sustainability to Support End-toEnd Value Chains: The Role of Supply Chain Management. Journal of the Academy of Marketing Science, 39(1), 101-116.

Cook, Deborah J, Mulrow, Cynthia D, and Haynes, R Brian. 1997. Systematic Reviews: Synthesis of Best Evidence for Clinical Decisions. Annals of internal medicine, 126(5), 376-380.

Cravens, David W, Ingram, Thomas N, LaForge, Raymond W, and Young, Clifford E. 1993. Behavior-Based and Outcome-Based Salesforce Control Systems. The Journal of Marketing, 47-59.

Cron, William L, Dubinsky, Alan J, and Michaels, Ronald E. 1988. The Influence of Career Stages on Components of Salesperson Motivation. The Journal of Marketing, 78-92.

Davis, Fred D, Bagozzi, Richard P, and Warshaw, Paul R. 1992. Extrinsic and Intrinsic Motivation to Use Computers in the Workplace1. Journal of Applied Social Psychology, 22(14), 1111-1132.

De Dreu, Carsten KW. 2006. When Too Little or Too Much Hurts: Evidence for a Curvilinear Relationship between Task Conflict and Innovation in Teams. Journal of Management, 32(1), 83-107.

DeCarlo, Thomas E, Teas, R Kenneth, and McElroy, James C. 1997. Salesperson Performance Attribution Processes and the Formation of Expectancy Estimates. Journal of Personal Selling \& Sales Management, 17(3), 1-17.

Deci, Edward L. 1971. Effects of Externally Mediated Rewards on Intrinsic Motivation. Journal of personality and social psychology, 18(1), 105.

Deci, Edward L. 1975. Intrinsic Motivation: Plenum Press. 
Deci, Edward L, and Ryan, Richard M. 1980. The Empirical Exploration of Intrinsic Motivational Processes. Advances in experimental social psychology, 13(2), 39-80.

Deci, Edward L, and Ryan, Richard M. 1985a. The General Causality Orientations Scale: SelfDetermination in Personality. Journal of Research in personality, 19(2), 109-134.

Deci, Edward L, and Ryan, Richard M. 1985b. Intrinsic Motivation and Self-Determination in Human Behavior: Springer.

Deci, Edward L, and Ryan, Richard M. 2002. Handbook of Self-Determination Research: University Rochester Press.

der Borgh, Michel, de Jong, Ad, and Nijssen, Edwin J. 2015. Alternative Mechanisms Guiding Salespersons' Ambidextrous Product Selling. British Journal of Management.

Doyle, S. X., and Shapiro, B. P. 1980. What Counts Most in Motivating Young Salesforce. Harvard Business Review, May-June, 133-140.

Dubinsky, Alan J, Jolson, Marvin A, Michaels, Ronald E, Kotabe, Masaaki, and Lim, Chae Un. 1993. Perceptions of Motivational Components: Salesmen and Saleswomen Revisited. Journal of Personal Selling \& Sales Management, 13(4), 25-37.

Dubinsky, Alan J, Kotabe, Masaaki, Lim, Chae Un, and Michaels, Ronald E. 1994. Differences in Motivational Perceptions among Us, Japanese, and Korean Sales Personnel. Journal of Business Research, 30(2), 175-185.

Dubinsky, Alan J, and Skinner, Steven J. 2002. Going the Extra Mile: Antecedents of Salespeople's Discretionary Effort. Industrial Marketing Management, 31(7), 589598.

Erevelles, Sunil, Fukawa, Nobuyuki, and Swayne, Linda. 2016. Big Data Consumer Analytics and the Transformation of Marketing. Journal of Business Research, 69(2), 897-904.

Evans, Kenneth R, Margheim, Loren, and Schlatter, John L. 1982. A Review of Expectancy Theory Research in Selling. Journal of Personal Selling \& Sales Management, 2(2), 3340.

Everly, George S, and Girdano, Daniel A. 1980. The Stress Mess Solution: The Causes and Cures of Stress on the Job: RJ Brady Co.

Fang, Eric, Palmatier, Robert W, and Evans, Kenneth R. 2004. Goal-Setting Paradoxes? Trade-Offs between Working Hard and Working Smart: The United States Versus China. Journal of the Academy of Marketing Science, 32(2), 188-202.

Ferri-Reed, Jan. 2010. The Keys to Engaging Millennials. Engineering Management Review, IEEE, 39(2), 42-45.

Fine, Leslie M, and Pullins, Ellen Bolman. 1998. Peer Mentoring in the Industrial Sales Force: An Exploratory Investigation of Men and Women in Developmental Relationships. Journal of Personal Selling \& Sales Management, 18(4), 89-103.

Fisher, Anne 2015. Young Workers Don't Want Sales Jobs. How to Convince Them Otherwise. Retrieved from Fortune website: http://fortune.com/2015/12/17/millennials-sales-jobs-recruiting-gen-z/

France, Stephen L, and Ghose, Sanjoy. 2016. An Analysis and Visualization Methodology for Identifying and Testing Market Structure. Marketing Science, 35(1), 182-197.

Fu, Frank Q, Elliott, Michael T, Mano, Haim, and Galloway, Chris. 2017. The Role of Affective Brand Commitment on Sales Effort. Journal of Marketing Theory and Practice, 25(3), 257-273.

Fu, Frank Q, Richards, Keith A, and Jones, Eli. 2009. The Motivation Hub: Effects of Goal Setting and Self-Efficacy on Effort and New Product Sales. Journal of Personal Selling and Sales Management, 29(3), 277-292. 
Fujimoto, Yuka, Ferdous, Ahmed Shahriar, Sekiguchi, Tomoki, and Sugianto, Ly-Fie. 2016. The Effect of Mobile Technology Usage on Work Engagement and Emotional Exhaustion in Japan. Journal of Business Research, 69(9), 3315-3323.

Gagne, Marylene, and Deci, Edward L. 2005. Self-Determination Theory and Work Motivation. Journal of Organizational Behavior, 26(4), 331-362.

Grant, K., Cravens, D. W., Low, G. S., and Moncrief, W. C. 2001. The Role of Satisfaction with Territory Design on the Motivation, Attitudes, and Work Outcomes of Salespeople. Journal of the Academy of Marketing Science, 29(2), 165-178.

Greenhaus, Jeffrey H, Collins, Karen M, and Shaw, Jason D. 2003. The Relation between Work-Family Balance and Quality of Life. Journal of vocational behavior, 63(3), 510531.

Guay, Frederic, Blais, Marc R, Vallerand, Robert J, and Pelletier, Luk G. 1999. The Global Motivation Scale. Unpublished manuscript, Université duq Uébec aMontréal.

Guay, Frederic, Mageau, Genevieve A, and Vallerand, Robert J. 2003. On the Hierarchical Structure of Self-Determined Motivation: A Test of Top-Down, Bottom-up, Reciprocal, and Horizontal Effects. Personality and Social Psychology Bulletin, 29(8), 992-1004.

Guay, Frederic, Vallerand, Robert J, and Blanchard, Celine. 2000. On the Assessment of Situational Intrinsic and Extrinsic Motivation: The Situational Motivation Scale (Sims). Motivation and emotion, 24(3), 175-213.

Hackman, J Richard, and Oldham, Greg R. 1974. The Job Diagnostic Survey: An Instrument for the Diagnosis of Jobs and the Evaluation of Job Redesign Projects.

Hackman, J Richard, and Oldham, Greg R. 1976. Motivation through the Design of Work: Test of a Theory. Organizational Behavior and Human Performance, 16(2), 250-279.

Hansen, Jared M, and Levin, Michael A. 2016. The Effect of Apathetic Motivation on Employees' Intentions to Use Social Media for Businesses. Journal of Business Research, 69(12), 6058-6066.

Harris, Eric G, Mowen, John C, and Brown, Tom J. 2005. Re-Examining Salesperson Goal Orientations: Personality Influencers, Customer Orientation, and Work Satisfaction. Journal of the Academy of Marketing Science, 33(1), 19-35.

He, Hongwei, Wang, Weiyue, Zhu, Weichun, and Harris, Lloyd. 2015. Service Workers' Job Performance: The Roles of Personality Traits, Organizational Identification, and Customer Orientation. European Journal of Marketing., 49(11/12), 1751-1776.

Heider, F. 1958. The Psychology of Interpersonal Relations: Lawrence Erlbaum Associates, Incorporated.

Hohenberg, Sebastian, and Homburg, Christian. 2016. Motivating Sales Reps for Innovation Selling in Different Cultures. Journal of Marketing, 80(2), 101-120.

House, Robert J, Shapiro, H Jack, and Wahba, Mahmoud A. 1974. Expectancy Theory as a Predictor of Work Behaviour and Attitude: A Re-Evaluation of Empirical Evidence. Decision Sciences, 5(3), 481-506.

Ingram, Thomas N, and Bellenger, Danny N. 1983. Personal and Organizational Variables: Their Relative Effect on Reward Valences of Industrial Salespeople. Journal of Marketing Research, 198-205.

Ingram, Thomas N, LaForge, Raymond W, and Leigh, Thomas W. 2002. Selling in the New Millennium: A Joint Agenda. Industrial Marketing Management, 31(7), 559-567. 
Ingram, Thomas N, Lee, Keun S, and Skinner, Steven J. 1989. An Empirical Assessment of Salesperson Motivation, Commitment, and Job Outcomes. The Journal of Personal Selling and Sales Management, 25-33.

Janson, Marius, Austin, Traci, and Hynes, Geraldine E. 2014. Groupware Design, Implementation, and Use: A Case Study. Journal of Management Information and Decision Sciences, 17(2), 135.

Jaramillo, Fernando, Locander, William B, Spector, Paul E, and Harris, Eric G. 2007. Getting the Job Done: The Moderating Role of Initiative on the Relationship between Intrinsic Motivation and Adaptive Selling. Journal of Personal Selling and Sales Management, 27(1), 59-74.

Jaramillo, Fernando, and Mulki, Jay Prakash. 2008. Sales Effort: The Intertwined Roles of the Leader, Customers, and the Salesperson. Journal of Personal Selling and Sales Management, 28(1), 37-51.

Jaramillo, Fernando, Mulki, Jay Prakash, and Marshall, Greg W. 2005. A Meta-Analysis of the Relationship between Organizational Commitment and Salesperson Job Performance: 25 Years of Research. Journal of Business Research, 58(6), 705-714.

Jasmand, Claudia, Blazevic, Vera, and de Ruyter, Ko. 2012. Generating Sales While Providing Service: A Study of Customer Service Representatives' Ambidextrous Behavior. Journal of Marketing, 76(1), 20-37.

John, George, and Weitz, Barton. 1989. Salesforce Compensation: An Empirical Investigation of Factors Related to Use of Salary Versus Incentive Compensation. Journal of Marketing Research, 1-14.

Johnston, M. W., and Marshall, G. W. 2005. Churchill/Ford/Walker's Sales Force Management. Boston: McGraw-Hill Education.

Jones, Eli, Brown, Steven P, Zoltners, Andris A, and Weitz, Barton A. 2005. The Changing Environment of Selling and Sales Management. Journal of Personal Selling \& Sales Management, 25(2), 105-111.

Kanfer, Ruth, Frese, Michael, and Johnson, Russell E. 2017. Motivation Related to Work: A Century of Progress. Journal of Applied Psychology, 102(3), 338.

Karkoulian, Silva, Srour, Jordan, and Sinan, Tala. 2016. A Gender Perspective on Work-Life Balance, Perceived Stress, and Locus of Control. Journal of Business Research, 69(11), 4918-4923.

Katz, Daniel, and Kahn, Robert Louis. 1978. The Social Psychology of Organizations (Vol. 2): Wiley New York.

Keaveney, Susan M, and Nelson, James E. 1993. Coping with Organizational Role Stress: Intrinsic Motivational Orientation, Perceived Role Benefits, and Psychological Withdrawal. Journal of the Academy of Marketing Science, 21(2), 113-124.

Keck, Kay L, Leigh, Thomas W, and Lollar, James G. 1995. Critical Success Factors in Captive, Multi-Line Insurance Agency Sales. Journal of Personal Selling \& Sales Management, 15(1), 17-33.

Kemp, Elyria, Borders, Aberdeen Leila, and Ricks, Joe M. 2013. Sales Manager Support: Fostering Emotional Health in Salespeople. European Journal of Marketing., 47(3/4), 635-654.

Keszey, Tamara, and Biemans, Wim. 2016. Sales-Marketing Encroachment Effects on Innovation. Journal of Business Research, 69(9), 3698-3706.

Kishore, Sunil, Rao, Raghunath Singh, Narasimhan, Om, and John, George. 2013. Bonuses Versus Commissions: A Field Study. Journal of Marketing Research, 50(3), 317-333. 
Kruglanski, Arie W, Thompson, Erik P, Higgins, E Tory, Atash, M, Pierro, Antonio, Shah, James $\mathrm{Y}$, and Spiegel, Scott. 2000. To" Do the Right Thing" or to" Just Do It": Locomotion and Assessment as Distinct Self-Regulatory Imperatives. Journal of personality and social psychology, 79(5), 793.

Kuruzovich, Jason. 2013. Sales Technologies, Sales Force Management, and Online Infomediaries. Journal of Personal Selling \& Sales Management, 33(2), 211-224.

Levin, Michael A, Hansen, Jared M, and Laverie, Debra A. 2012. Toward Understanding New Sales Employees' Participation in Marketing-Related Technology: Motivation, Voluntariness, and Past Performance. Journal of Personal Selling \& Sales Management, 32(3), 379-393.

Lo, Desmond, Ghosh, Mrinal, and Lafontaine, Francine. 2011. The Incentive and Selection Roles of Sales Force Compensation Contracts. Journal of Marketing Research, 48(4), 781-798.

Low, G. S., Cravens, D. W., Grant, K., and Moncrief, W. C. 2001. Antecedents and Consequences of Salesperson Burnout. European Journal of Marketing., 35, 587-611.

MacInnis, Deborah J, Moorman, Christine, and Jaworski, Bernard J. 1991. Enhancing and Measuring Consumers' Motivation, Opportunity, and Ability to Process Brand Information from Ads. The Journal of Marketing, 32-53.

MacKenzie, Scott B, Podsakoff, Philip M, and Ahearne, Michael. 1998. Some Possible Antecedents and Consequences of in-Role and Extra-Role Salesperson Performance. The Journal of Marketing, 87-98.

Mallin, Michael L, and Pullins, Ellen Bolman. 2009. The Moderating Effect of Control Systems on the Relationship between Commission and Salesperson Intrinsic Motivation in a Customer Oriented Environment. Industrial Marketing Management, 38(7), 769-777.

March, James G. 1991. Exploration and Exploitation in Organizational Learning. Organization science, 2(1), 71-87.

Marks, Stephen R, and MacDermid, Shelley M. 1996. Multiple Roles and the Self: A Theory of Role Balance. Journal of Marriage and the Family, 417-432.

Marshall, Greg W, Moncrief, William C, Rudd, John M, and Lee, Nick. 2012. Revolution in Sales: The Impact of Social Media and Related Technology on the Selling Environment. Journal of Personal Selling \& Sales Management, 32(3), 349-363.

Menguc, Bulent, Auh, Seigyoung, Yeniaras, Volkan, and Katsikeas, Constantine S. 2017. The Role of Climate: Implications for Service Employee Engagement and Customer Service Performance. Journal of the Academy of Marketing Science, 45(3), 428-451.

Menguc, Bulent, and Barker, A. Tansu. 2003. The Performance Effects of Outcome-Based Incentive Pay Plans on Sales Organisations: A Contextual Analysis. Journal of Personal Selling \& Sales Management, 23(4), 341-358.

Miao, C Fred, and Evans, Kenneth R. 2007. The Impact of Salesperson Motivation on Role Perceptions and Job Performance-a Cognitive and Affective Perspective. Journal of Personal Selling and Sales Management, 27(1), 89-101.

Miao, C Fred, and Evans, Kenneth R. 2012. Effects of Formal Sales Control Systems: A Combinatory Perspective. International Journal of Research in Marketing, 29(2), 181191.

Miao, C Fred, and Evans, Kenneth R. 2014. Motivating Industrial Salesforce with Sales Control Systems: An Interactive Perspective. Journal of Business Research. 
Miao, C Fred, Evans, Kenneth R, and Zou, Shaoming 2007. The Role of Salesperson Motivation in Sales Control Systems-Intrinsic and Extrinsic Motivation Revisited. Journal of Business Research, 60(5), 417-425.

Miao, C Fred, Lund, Donald J, and Evans, Kenneth R. 2009. Reexamining the Influence of Career Stages on Salesperson Motivation: A Cognitive and Affective Perspective. Journal of Personal Selling \& Sales Management, 29(3), 243-255.

Miao, C Fred, and Wang, Guangping. 2016. The Differential Effects of Functional Vis-À-Vis Relational Customer Orientation on Salesperson Creativity. Journal of Business Research, 69(12), 6021-6030.

Michel, Géraldine, Merk, Michaela, and Eroglu, Sevgin. 2015. Salesperson-Brand Relationship: Main Dimensions and Impact within the Context of Private Brand Retailing. Journal of Personal Selling \& Sales Management, 35(4), 314-333.

Mitchell, Terence R. 1982. Motivation: New Directions for Theory, Research, and Practice. Academy of management review, 80-88.

Moncrief, William C, and Marshall, Greg W. 2005. The Evolution of the Seven Steps of Selling. Industrial Marketing Management, 34(1), 13-22.

Moncrief, William C, Marshall, Greg W, and Watkins, Courtney. 2000. Tracking Academic Research in Selling and Sales Management: Authors, Authorships, Academic Institutions, and Journals. The Journal of Personal Selling and Sales Management, 99108.

Murphy, William H. 2004. In Pursuit of Short-Term Goals: Anticipating the Unintended Consequences of Using Special Incentives to Motivate the Sales Force. Journal of Business Research, 57(11), 1265-1275.

Narus, James A. . 2015. B2b Salespeople Can Survive If They Reimagine Their Roles. Harvard Business Review.

Oliver, Richard L. 1974. Expectancy Theory Predictions of Salesmen's Performance. Journal of Marketing Research, 243-253.

Oliver, Richard L, and Anderson, Erin. 1994. An Empirical Test of the Consequences of Behavior-and Outcome-Based Sales Control Systems. The Journal of Marketing, 5367.

Palmatier, Robert W., Houston, Mark B., and Hulland, John. 2017. Review Articles: Purpose, Process, and Structure. Journal of the Academy of Marketing Science.

Parasuraman, Ananthanarayanan. 2000. Technology Readiness Index (Tri) a Multiple-Item Scale to Measure Readiness to Embrace New Technologies. Journal of Service Research, 2(4), 307-320.

Pettijohn, Charles E, Pettijohn, Linda S, and Taylor, Albert J. 2002. The Influence of Salesperson Skill, Motivation, and Training on the Practice of Customer-Oriented Selling. Psychology \& Marketing, 19(9), 743-757.

Pink, Daniel H. 2010. Drive: The Surprising Truth About What Motivates Us: Canongate.

Pink, Daniel H. 2012. A Radical Prescription for Sales. Retrieved from Harvard Business Review website: https://hbr.org/2012/07/a-radical-prescription-for-sales

Pullins, Ellen Bolman. 2001. An Exploratory Investigation of the Relationship of Sales Force Compensation and Intrinsic Motivation. Industrial Marketing Management, 30(5), 403-413.

Pullins, Ellen Bolman, Haugtvedt, Curtis P, Dickson, Peter R, Fine, Leslie M, and Lewicki, Roy J. 2000. Individual Differences in Intrinsic Motivation and the Use of Cooperative Negotiation Tactics. Journal of Business \& Industrial Marketing, 15(7), 466-478. 
Pullins, Ellen Bolman, Mallin, Michael L, Buehrer, Richard E, and Jones, Deirdre E. 2011. How Salespeople Deal with Intergenerational Relationship Selling. Journal of Business \& Industrial Marketing, 26(6), 443-455.

Richards, Keith A, Moncrief, William C, and Marshall, Greg W. 2010. Tracking and Updating Academic Research in Selling and Sales Management: A Decade Later. Journal of Personal Selling \& Sales Management, 30(3), 253-271.

Robbins, Stephen P. 2009. Organizational Behavior: Pearson Education.

Roman, Sergio, and lacobucci, Dawn. 2010. Antecedents and Consequences of Adaptive Selling Confidence and Behavior: A Dyadic Analysis of Salespeople and Their Customers. Journal of the Academy of Marketing Science, 38(3), 363-382.

Roman, Sergio, Ruiz, Salvador, and Munuera, Jose Luis. 2005. The Influence of the Compensation System and Personal Variables on a Salesperson's Effective Listening Behaviour. Journal of Marketing Management, 21(1-2), 205-230.

Rutherford, Brian N., Marshall, Greg W., and Park, JungKun. 2014. The Moderating Effects of Gender and inside Versus Outside Sales Role in Multifaceted Job Satisfaction. Journal of Business Research, 67(9), 1850-1856.

Ryan, Richard M. 1995. Psychological Needs and the Facilitation of Integrative Processes. Journal of personality, 63(3), 397-427.

Ryan, Richard M, and Deci, Edward L. 2000a. Intrinsic and Extrinsic Motivations: Classic Definitions and New Directions. Contemporary educational psychology, 25(1), 54-67.

Ryan, Richard M, and Deci, Edward L. 2000b. Self-Determination Theory and the Facilitation of Intrinsic Motivation, Social Development, and Well-Being. American psychologist, 55(1), 68-78.

Schaufeli, Wilmar B, Salanova, Marisa, González-Romá, Vicente, and Bakker, Arnold B. 2002. The Measurement of Engagement and Burnout: A Two Sample Confirmatory Factor Analytic Approach. Journal of Happiness studies, 3(1), 71-92.

Schmitz, Christian. 2013. Group Influences of Selling Teams on Industrial Salespeople's Cross-Selling Behavior. Journal of the Academy of Marketing Science, 41(1), 55-72.

Schulman, Peter. 1999. Applying Learned Optimism to Increase Sales Productivity. Journal of Personal Selling \& Sales Management, 19(1), 31-37.

Schultz, Roberta J, Schwepker, CH, Davidson, M, and Davidson, P. 2012. Boomers Vs. Millennials: Critical Conflict Regarding Sales Culture, Salesforce Recognition, and Supervisor Expectations. International Journal of Business, Humanities and Technology, 2(1), 32-41.

Segalla, Michael, Rouziès, Dominique, Besson, Madeleine, and Weitz, Barton A. 2006. A Cross-National Investigation of Incentive Sales Compensation. International Journal of Research in Marketing, 23(4), 419-433.

Selye, Hans. 1978. The Stress of Life: Rev Ed: McGraw-Hill.

Shi, Huanhuan, Sridhar, Shrihari, Grewal, Rajdeep, and Lilien, Gary. 2017. Sales Representative Departures and Customer Reassignment Strategies in Business-toBusiness Markets. Journal of Marketing, 81(2), 25-44.

Shojania, Kaveh G, Sampson, Margaret, Ansari, Mohammed T, Ji, Jun, Doucette, Steve, and Moher, David. 2007. How Quickly Do Systematic Reviews Go out of Date? A Survival Analysis. Annals of internal medicine, 147(4), 224-233.

Singh, Jagdip. 1998. Striking a Balance in Boundary-Spanning Positions: An Investigation of Some Unconventional Influences of Role Stressors and Job Characteristics on Job Outcomes of Salespeople. The Journal of Marketing, 69-86. 
Smith, Kirk, Jones, Eli, and Blair, Edward. 2000. Managing Salesperson Motivation in a Territory Realignment. The Journal of Personal Selling and Sales Management, 215226.

Sok, Keo Mony, Sok, Phyra, and De Luca, Luigi M. 2016. The Effect of 'Can Do'and 'Reason To'motivations on Service-Sales Ambidexterity. Industrial Marketing Management, 55, 144-155.

Spence, Janet T, Helmreich, Robert L, and Pred, Robert S. 1987. Impatience Versus Achievement Strivings in the Type a Pattern: Differential Effects on Students' Health and Academic Achievement. Journal of Applied Psychology, 72(4), 522.

Spence, Janet T, and Robbins, Ann S. 1992. Workaholism: Definition, Measurement, and Preliminary Results. Journal of personality assessment, 58(1), 160-178.

Spiro, Rosann L, and Weitz, Barton A. 1990. Adaptive Selling: Conceptualization, Measurement, and Nomological Validity. Journal of Marketing Research, 61-69.

Stathakopoulos, Vlasis. 1996. Sales Force Control: A Synthesis of Three Theories. Journal of Personal Selling \& Sales Management, 16(2), 1-12.

Steel, Piers, and Konig, Cornelius J. 2006. Integrating Theories of Motivation. Academy of management review, 31(4), 889-913.

Steenburgh, Thomas, and Ahearne, Michael. 2012. Motivating Salespeople: What Really Works. Harvard Business Review, 90(7-8), 70.

Stock, Ruth Maria. 2006. Interorganizational Teams as Boundary Spanners between Supplier and Customer Companies. Journal of the Academy of Marketing Science, 34(4), 588599.

Stros, Michael, and Lee, Nick. 2015. Marketing Dimensions in the Prescription Pharmaceutical Industry: A Systematic Literature Review. Journal of Strategic Marketing, 23(4), 318-336.

Sujan, Harish. 1986. Smarter Versus Harder: An Exploratory Attributional Analysis of Salespeople's Motivation. Journal of Marketing Research, 41-49.

Sujan, Harish, Weitz, Barton A, and Kumar, Nirmalya. 1994. Learning Orientation, Working Smart, and Effective Selling. The Journal of Marketing, 39-52.

Tanner, Emily C, Tanner, John F, and Wakefield, Kirk. 2015. Panacea or Paradox? The Moderating Role of Ethical Climate. Journal of Personal Selling \& Sales Management, 35(2), 175-190.

Teas, R Kenneth. 1980. An Empirical Test of Linkages Proposed in the Walker, Churchill, and Ford Model of Salesforce Motivation and Performance. Journal of the Academy of Marketing Science, 8, 58-72.

Teas, R Kenneth. 1981. An Empirical Test of Models of Salespersons, Job Expectancy and Instrumentality Perceptions. Journal of Marketing Research, 209-226.

Teas, R Kenneth, and McElroy, James C. 1986. Causal Attributions and Expectancy Estimates: A Framework for Understanding the Dynamics of Salesforce Motivation. The Journal of Marketing, 75-86.

Teo, Thompson SH, Lim, Vivien KG, and Lai, Raye YC. 1999. Intrinsic and Extrinsic Motivation in Internet Usage. Omega, 27(1), 25-37.

Tranfield, David, Denyer, David, and Smart, Palminder. 2003. Towards a Methodology for Developing Evidence-Informed Management Knowledge by Means of Systematic Review. British Journal of Management, 14(3), 207-222.

Tushman, Michael L, and O'Reilly, Charles A. 1996. Ambidextrous Organizations: Managing Evolutionary and Revolutionary Change. California Management Review, 38(4), 8-29. 
Tyagi, Pradeep K. 1982. Perceived Organizational Climate and the Process of Salesperson Motivation. Journal of Marketing Research, 240-254.

Tyagi, Pradeep K. 1985a. The Effects on Stressful Organizational Conditions on Salesperson Work Motivation. Journal of the Academy of Marketing Science, 13(1-2), 290-309.

Tyagi, Pradeep K. 1985b. Organizational Climate, Inequities, and Attractiveness of Salesperson Rewards. The Journal of Personal Selling and Sales Management, 31-37.

Tyagi, Pradeep K. 1985c. Relative Importance of Key Job Dimensions and Leadership Behaviors in Motivating Salesperson Work Performance. The Journal of Marketing, 76-86.

Van Eerde, Wendelien, and Thierry, Henk. 1996. Vroom's Expectancy Models and WorkRelated Criteria: A Meta-Analysis. Journal of Applied Psychology, 81(5), 575.

Vancouver, Jeffrey B. 2008. Integrating Self-Regulation Theories of Work Motivation into a Dynamic Process Theory. Human resource management review, 18(1), 1-18.

Vancouver, Jeffrey B, Weinhardt, Justin M, and Schmidt, Aaron M. 2010. A Formal, Computational Theory of Multiple-Goal Pursuit: Integrating Goal-Choice and GoalStriving Processes. Journal of Applied Psychology, 95(6), 985.

Venkatesh, Viswanath, and Davis, Fred D. 2000. A Theoretical Extension of the Technology Acceptance Model: Four Longitudinal Field Studies. Management science, 46(2), 186204.

Verbeke, Willem, Belschak, Frank, and Bagozzi, Richard P. 2004. The Adaptive Consequences of Pride in Personal Selling. Journal of the Academy of Marketing Science, 32(4), 386402.

Verbeke, Willem, Dietz, Bart, and Verwaal, Ernst. 2011. Drivers of Sales Performance: A Contemporary Meta-Analysis. Have Salespeople Become Knowledge Brokers? Journal of the Academy of Marketing Science, 39(3), 407-428.

Vroom, Victor Harold. 1964. Work and Motivation (Vol. 54): Wiley New York.

Walker, Orville C, Churchill , Gilbert A, and Ford, Neil M. 1977. Motivation and Performance in Industrial Selling: Present Knowledge and Needed Research. Journal of Marketing Research, 156-168.

Walton, Richard E. 1969. Interpersonal Peacemaking: Confrontations and Third-Party Consultation (Vol. 1): Addison-Wesley.

Warr, Peter, Cook, John, and Wall, Toby. 1979. Scales for the Measurement of Some Work Attitudes and Aspects of Psychological Well-Being. Journal of occupational psychology, 52(2), 129-148.

Weiner, Bernard. 1980. Human Motivation: New York: Holt, Rinehart and Winston.

Weiner, Bernard. 1995. Intrinsic Motivation. In M. Manstead, S. Hewstone, M. Fiske, H. Hoggs andG. Samin Reis (Eds.), The Blackwell Encyclopedia of Social Psychology (pp. 341). Cambridge, UK:: Blackwell.

Weitz, Barton A, Sujan, Harish, and Sujan, Mita. 1986. Knowledge, Motivation, and Adaptive Behavior: A Framework for Improving Selling Effectiveness. The Journal of Marketing, 174-191.

White, Robert W. 1959. Motivation Reconsidered: The Concept of Competence. Psychological review, 66(5), 297.

Williams, Brian C, and Plouffe, Christopher R. 2007. Assessing the Evolution of Sales Knowledge: A 20-Year Content Analysis. Industrial Marketing Management, 36(4), 408-419. 
Womack, Brian. 2017. Oracle's Push into Cloud Gathers More Momentum on Sales Growth. Retrieved from Bloomberg Technology website:

https://www.bloomberg.com/news/articles/2017-09-14/oracle-s-push-into-cloudgathers-more-momentum-on-sales-growth

Wotruba, Thomas R, MacFie, John S, and Colletti, Jerome A. 1991. Effective Sales Force Recognition Programs. Industrial Marketing Management, 20(1), 9-15.

Yidong, Tu, and Xinxin, Lu. 2013. How Ethical Leadership Influence Employees' Innovative Work Behavior: A Perspective of Intrinsic Motivation. Journal of business ethics, 116(2), 441-455.

Zhang, Xiaomeng, and Bartol, Kathryn M. 2010. Linking Empowering Leadership and Employee Creativity: The Influence of Psychological Empowerment, Intrinsic Motivation, and Creative Process Engagement. Academy of management Journal, 53(1), 107-128.

Zoltners, Andris A, Sinha, PK, and Lorimer, Sally E. 2013. The Growing Power of inside Sales. Harvard Business Review. Retrieved from Harvard Business Review website: https://hbr.org/2013/07/the-growing-power-of-inside-sa

Zoltners, Andris A, Sinha, PK, and Lorimer, Sally E. 2017. Sales Bonuses Are Supposed to Motivate, So Don't Waste Them on Easy Targets. Retrieved from Harard Business Review website: https://hbr.org/2017/09/sales-bonuses-are-supposed-to-motivateso-dont-waste-them-on-easy-targets 